\begin{tabular}{|lcc|}
\hline & $\begin{array}{c}\text { Osmanlı Medeniyeti Araştırmaları Dergisi } \\
\text { Journal of Ottoman Civilization Studies } \\
\text { Sayı 12, Nisan 2021 \& No 12, April } 2021\end{array}$ \\
e-ISSN 2458-9519 & C2021 Telif Hakkı OSMED'e aittir & Article Types: Research Article \\
\hline DOI: 10.21021 /osmed.901068 & Makale Türü: Araştırma Makalesi & OSMED, 2021, (12): 42-58 \\
\hline Geliş Tarihi \& Received: 22.03 .2021 & Kabul Tarihi \& Accepted: 04.04.2021 &
\end{tabular}

\title{
Hatay'da Bir Okul-Kilise: Kırıkhan Ruhban Okulu
}

\section{A School-Church in Hatay: Kırıkhan Seminary School}

\section{Servet Özkan*}

\section{$\ddot{\mathbf{O z}}$}

Osmanlı Devleti'nde 19. yüzyıl, misyonerlik faaliyetlerinin yoğun olarak yaşandığı bir dönemi kapsamıştır. Oluşan bu yoğunlukta, Tanzimat (1839) ve Islahat Fermanlarının (1856) ilan edilmesi sonrasında gelen reformların ve yabanc1 devletlere tanınan imtiyazların büyük etkisi olmuştur. Yüzyıl boyunca Osmanlı, her alanda eğitimli bireyler yetiştirmek için yeni okullar inşa ederken, yabancı devletler de Osmanlı topraklarında eğitim kurumu açma hakkına sahip olmuştur. Bu nedenle Amerika, Fransa, İngiltere, Almanya ve İtalya gibi devletler, elde ettikleri çeşitli ayrıcalıklarla Osmanlı coğrafyasında birçok okul açmış ve bu okullar aracılığı ile misyonerlik faaliyetleri yürütmüştür. Bu devletlerden Fransa, daha önce elde ettiği kapitülasyonlar sayesinde Osmanlıdaki misyonerlik çalışmalarına ve okullaşma faaliyetlerine erken başlama imkânı bulmuştur. Fransa'nın gönderdiği çeşitli misyoner gruplar, İstanbul ve Anadolu'nun pek çok yerinde okul açma çalışmalarını hızlandırmıştır. Bunlara örnek eğitim kurumlarından biri de Hatay'ın Kırıkhan ilçesinde bulunmaktadır. Cizvit ve Lazarist misyonerlerinin iş birliği ile açılan ve Kırıkhan Ruhban Okulu olarak anılan okul, Fransız eğitim kurumları içinde plan kuruluşu ve mimari özellikleri ile farklı bir örnek teşkil etmektedir. Okul ve kilisenin tek yapı bünyesinde birleşmesi, Kırıkhan Ruhban Okulu'nun diğer Fransız okullarından ayrılması ve ünik bir örnek olarak değerlendirilmesi açısından önem arz etmektedir. Bunun yanı sıra cephe biçimlenişi ve farklı pencere düzeniyle de okul kendine has özellikler taşımaktadır. Çoğunlukla tarih alanında yapılmış çalışmalara konu olduğu görülen yapının, sanat ve mimarlık tarihi disipliniyle kapsamlı olarak değerlendirilmediği anlaşılmaktadır. Bu çalışmada okul, mimari özellikleri ile tanıtılmış ve sanat tarihi disiplini çerçevesinde detaylı olarak incelenmiştir.

Anahtar Kelimeler: Hatay, Kırıkhan, Fransa, Misyonerlik, Eğitim, Kırıkhan Ruhban Okulu.

\begin{abstract}
The 19th century covered a period of intense missionary activity in the Ottoman Empire. In this intensity, the reforms that followed the declaration of the Tanzimat (1839) and the Islahat edicts (1856) and the concessions granted to foreign states had a great impact. During the century, the Ottoman Empire built new schools to train educated people in all areas, while foreign states also had the right to open educational institutions on Ottoman territory. For this reason, states such as America, France, England, Germany and Italy opened many schools in the Ottoman geography with various privileges they obtained and carried out missionary activities through these schools. One of these states, France, had the opportunity to start early missionary studies and schooling activities in the Ottoman Empire thanks to the capitulations it had previously obtained. Various missionary groups sent by France have accelerated schooling activities in many parts of Istanbul and Anatolia. One of these educational institutions located in Kirikhan district of Hatay. The school, which was opened with the cooperation of Jesuit and Lazarist missionaries and known as Kirıkhan Seminary School, sets a different example with its plan establishment and architectural features among French educational institutions. The unification of the school and the church under a single structure is important in terms of separating Kirıkhan Seminary School from other French schools and considering it as a unique example. In addition, the school has its own characteristics with its facade formation and different window layout. It is understood that the building, which is mostly the subject of studies in the field of history, has not been evaluated comprehensively with the discipline of art and architectural history. In this study, the school has been introduced with its architectural features and examined in detail within the framework of the art history discipline.
\end{abstract}

Keywords: Hatay, Kırıkhan, France, Missionary, Education, Kırıkhan Seminary School.

* (Arş. Görv.); Hatay Mustafa Kemal Üniversitesi, Sanat Tarihi Bölümü; Sakarya Üniversitesi Sosyal Bilimler Enstitüsü Sanat Tarihi Anabilim Dalı; cayanservet@gmail.com; ORCID: orcid.org/0000-0002-7113-9136.

Bu çalışma, yazar tarafından hazırlanmakta olan “Osmanlı'da Misyonerliğin Mimariye Yansımaları: Tanzimat Sonrası Misyoner ve Azınlık Okulları" konulu doktora tezinin bir bölümünden üretilmiştir. 


\section{Giriş}

Osmanlı İmparatorluğu'nun 19. yüzy1lı, Tanzimat (1839) ve Islahat Fermanlarının (1856) ilanı ile başlayan ve devletin her kademesinde yenilikçi bir takım politikaların hayata geçirilmeye çalışıldığı bir dönemdir. Yüzyılın ilk yarısında ilan edilen Tanzimat Fermanı ile hukukun üstünlüğüne dayalı yeni devlet düzeni kurulmaya çalışılmış ve pek çok yeni reform beraberinde gelmiştir. ${ }^{1}$ Osmanlı İmparatorluğu'nda meşruti bir yönetimin kurulmasını, Müslüman ve gayrimüslim cemaatlerin yakınlaşmasını amaçlayan Tanzimat hareketi; siyasi, idari, ekonomik ve toplumsal alanlarda değişimi hızlandırarak, Osmanlı'nın bütün sistemlerini dolaylı da olsa etkisi altına almıştır. ${ }^{2}$ Değişimin başladığı en önemli alanların başında gelen eğitim, askeri okullarda görülen iyileştirme çabalarının yaygınlaştırılıp, Batının örnek alındığı yeni eğitim kurumlarının gelişimi ile devam etmiştir. ${ }^{3}$ Bu gelişim, Tanzimat hareketinin bir sonucu olarak bütün Osmanlı toplumuna yayılmış ve gayrimüslim cemaatlere tanınan hak ve özgürlükler, onların da yeni eğitim kurumları açmalarını hızlandırmıştır. Ayrıca, dönemin reformlarının başında gelen Osmanlıcılık fikri, Müslüman ve gayrimüslim cemaatlerin kaynaşması ve beraber eğitim görmeleri için yeni idadi ve sultani mektepleri inşa edilmesini sağlamış ve gayrimüslim çocuklara da kapılarını açmıştır. ${ }^{4}$ Bunun en belirgin örneği olan Galatasaray Mekteb-i Sultanisi (1868), Osmanlı'nın bu dönemdeki reformist yaklaşımının bir ürünü olmakla birlikte, bütün Osmanlı tebaası öğrenciyi tek çatı altında toplama ve bir Osmanlı milleti oluşturma fikrinin somut bir yansımasıdır. ${ }^{5}$ Ancak, bu yenilik ve çabalara rağmen Osmanlı'nın eğitim sistemini olgunlaştıramaması, modern ve laik eğitimi hızla kurumsal hale getirememesi, gayrimüslim cemaatlerin ve yabancı devletlerin Osmanlı topraklarında okullar açmasını hızlandırmıştır. ${ }^{6}$

Osmanlıda toprak kayıplarının artması sonucu, öncelikle askeri alanda bir takım reform hareketleri başlamış ve 19. yüzyılda siyasi, ekonomik, sosyokültürel pek çok alanda yeni düzenlemeler hayata geçirilmeye çalışılmıştır. Osmanlının yenilik hareketleri, Batıyla daha yakın ilişkiler kurmasını sağlamıştır. $\mathrm{Bu}$ yakınlaşma, Batılı ülkelere bir takım imtiyazlar tanınması sonucunu da beraberinde getirmiştir. Çeşitli alanlarda kolaylık sağlayan bu imtiyazlar, Osmanlı topraklarındaki misyonerlik çalışmalarının dayanağı olmuş ve misyonerliğin en önemli ayağını oluşturan eğitim kanalıyla yaygın hale gelmiştir. ${ }^{7}$ Osmanlı tebaasından Katoliklerin koruyucusunun Fransa ve Avusturya, Protestanların koruyucusunun İngiltere ve Amerika, Ortodokslarınkinin ise Rusya olması, bu devletlerin açtığı eğitim kurumları aracılığıyla hem misyonerlik çalışması yürütmesini hem de gayrimüslimleri denetim altında tutma isteklerini gün yüzüne çıkarmıştır. ${ }^{8}$

Osmanlı'nın her alanda örnek aldığı ve etkileşim içinde olduğu Fransa, bu devletler içinde ayrıcalıklı konumu ile dikkat çekmiştir. 18. yüzyıl itibari ile Osmanlı'da Batılılaşma adımlarının atılmasında, çeşitli askeri reformlarda, mimari ve sanatsal alanlarda ilk örnek model olan Fransa, 19. yüzyıl Osmanlı eğitim sistemine de bir takım etkilerde bulunmuştur. ${ }^{9}$ Fransa'nın desteği ile açılan Galatasaray Mekteb-i Sultanisi

\footnotetext{
${ }^{1}$ Bülent Tanör, “Anayasal Gelişmelere Toplu Bir Bakış”. Tanzimat'tan Cumhuriyete Türkiye Ansiklopedisi, 1 (İstanbul 1985), s. 10; Bilal Eryılmaz, Tanzimat ve Yönetimde Modernleşme, (İstanbul: İ̧̧aret Yayınları, 2017), 97.

${ }^{2}$ Ahmet Cevat Eren, Tanzimat Fermanı ve Dönemi, (Istanbul: Derin Yayınları, 2007), 12; Bilal Eryılmaz, a.g.e., 97.

${ }^{3}$ Selçuk Uygun, "Türkiye'de Dünden Bugüne Özel Okullara Bir Bakış (Gelişim ve Etkileri)", Ankara Üniversitesi Eğitim Bilimleri Fakültesi Dergisi, 36/1-2 (2003): 109.

${ }^{4}$ Halis Ayhan, "Batılılaşma", İslam Ansiklopedisi, 5, (İstanbul: Türkiye Diyanet Vakfı Yayınları, 1992), 159.

${ }^{5}$ Adnan Şişman, "Galatasaray Mekteb-i Sultanisi", Islam Ansiklopedisi, 13, (İstanbul: Türkiye Diyanet Vakfı Yayınları, 1996), $323-326$.

6 Hidayet Vahapoğlu, Osmanlıdan Günümüze Azınlık ve Yabancı Okulları, (İstanbul: Boğaziçi Yayınları, 1992), 69; İlber Ortaylı, imparatorluğun En Uzun Yüzyılı, (İstanbul: illetişim Yayınları, 1995), 193-194; illknur Haydaroğlu, “Osmanlı İmparatorluğu’nda Yabancı Okullar", Türkler, 14, (Ankara: Yeni Türkiye Yayınları, 2002), 183; Selçuk Uygun, a.g.m., 109-110.

7 Ersoy Taşdemirci, "Türk Eğitim Tarihinde Azınlık Okulları ve Yabancı Okullar", Erciyes Üniversitesi Sosyal Bilimler Enstitüsü Dergisi, 10 (2001), 24-25.

8 Hidayet Vahapoğlu, a.g.e., 72; Remzi Kılıç, "Misyonerlik ve Türkiye'ye Yönelik Misyoner Faaliyetleri”, TÜBAR, 19 (2006); 335.

${ }^{9}$ Hüner Tuncer, "Yirmi Sekiz Çelebi Mehmet Efendi'nin Fransa Sefaretnamesi”, Belleten, LI/199 (1987), 131; Ekmelleddin Ihsanoğlu, Osmanlıda Eğitim ve Bilim Müesseseleri, Osmanlı Medeniyeti Tarihi, (ed. Ekmelleddin İhsanoğlu), I, (İstanbul: Feza Gazetecilik, 1999), 278; Zeki Arıkan, "Yirmisekiz Çelebi Mehmed Efendi", İslam Ansiklopedisi, 43, (İstanbul: Türkiye Diyanet Vakfı Yayınları, 2013 ); 551.
} 
(1868) bunun en belirgin örneğini temsil etmiştir. Ancak, Osmanlı Devleti’nin Fransa ile yakınlaşması sadece Batılılaşma hareketleri ile sınırlı olmamıştır. Zira 16. yüzyılda Fransa'ya tanınan ayrıcalıklar, çeşitli hakları ve misyonerlik faaliyetlerini de beraberinde getirmiştir. Elde ettiği ilk kapitülasyonlar sonrasında Fransa, Katolikleri ve tüm Hristiyanları himayesine almak istemiş ve 1583 'te Cizvit misyonerlerini İstanbul'a göndererek, Osmanlı'daki ilk yabancı eğitim kurumu olan St. Benoit Okulu'nu açmıştır. ${ }^{10}$ Bunları Fransisken, Dominiken, Kapüsen, Lazarit, Frer, Notre Dame de Sion, Assomption, İvrea, Filles de la Chariter gibi çoğunluğu Fransa himayesinde ya da Fransız soyundan gelen misyoner grupları takip etmiştir. ${ }^{11}$ Fransız İhtilali'nden (1789) sonra duraksayan misyoner faaliyetleri, 1830'lardan itibaren tekrar canlanmış ve Katolik misyonerlerin Doğu'da ve Afrika topraklarında ilerlemeye başlamasıyla oldukça geniş alanlara yayılmıştır. ${ }^{12}$

Fransız misyoner gruplar, Osmanlı coğrafyasının çeşitli yerlerinde kilise, okul ve sağlık kurumları açarak faaliyetlerini sürdürmüştür. Daha Tanzimat dönemi başlarında, çoğunluğu İstanbul' da bulunan, 21'i erkek ve 19'u kız okulu olmak üzere Fransa'nın birçok eğitim kurumu inşa ettiği görülmüştür. ${ }^{13}$ II. Abdülhamid dönemine gelindiğinde ise bu sayının 108'e ulaştığ bilinmektedir. $^{14}$

Fransız misyoner gruplarının faaliyet alanı olarak seçtiği yerlerden biri de bugünkü Hatay olmuştur. Kudüs'ten sonra önemli bir merkez konumunda olan Antakya, bu özelliği ile de misyonerleri cezbetmiştir. Özellikle 19. yüzyıl sonu ve 20. yüzyıl başlarında çeşitli Katolik misyonerleri, başta Antakya olmak üzere İskenderun, Hassa ve Kırıkhan'da aktif olarak çalışmıştır. ${ }^{15}$ Bu çalışmaların, Hatay'daki Fransız manda döneminde (1918-1938) daha da arttığı, Fransız yönetimi ve misyonerlerin birbirlerine destek olarak eğitim faaliyetlerine devam ettiği görülmüştür. ${ }^{16}$ Fransız yönetimi, manda dönemi sonlarına kadar yaklaşı 66 köy okulu inşa etmiş, Fransız dilini, tarihini ve kültürünü öğreterek bölgedeki hâkimiyetini güçlendirmek istemiştir. ${ }^{17}$

\section{Kırıkhan Ruhban Okulu}

\subsection{Tarihçesi}

Hatay sinırları dâhilinde, Kapusenler (Capucins), Lazaristler, Trapestler, Frerler ve Soeurs de St. Joseph de l'Apparition adlı Katolik misyoner grupları çalışmalarda bulunmuştur. ${ }^{18} \mathrm{Bu}$ gruplardan Lazarist misyonerleri, 1884'te Hatay Akbez'de bir manastır inşa etmiştir (Harita 1). 80 Ermeni aile ve 20 Marunî aileyi de içine alarak bu manastırda ikamet eden misyonerler, Akbez'in Ankara Anlaşması (1921) ile Türklere bırakılmasından sonra çalışmalarında hukuki engele takılarak İskenderun'a taşınmıştır. ${ }^{19}$ Milli mücadele döneminde bölgede yaşanan çatışmalar sırasında bu manastır binası yanmıştır. Daha sonra ise Fransız yönetimi ve Cizvit Papazlarının desteğini alan Lazarist misyonerleri, 1923'te Kırıkhan'ın Soğuksu

\footnotetext{
${ }^{10}$ Anonim, "Özel Eğitim Kurumları”, Türk Ansiklopedisi, XXVI, (Ankara: MEB Yayınları, 1977), 306; Yahya Akyüz, "Cevdet Paşa'nın Özel Öğretim ve Tanzimat Eğitimine Illişkin Bir Layihası”, Ankara Üniversitesi Osmanlı Tarihi Araştırma ve Uygulama Merkezi Dergisi, 3 (1992), 99.

11 Tülün Taş, “19. Yüzyılda Anadolu’da Katolik Misyonerlerin Eğitim Alanındaki Faaliyetleri” (yüksek lisans tezi, Erciyes Üniversitesi, 2006), 82.

12 Şerife Yorulmaz, "Osmanlı- Fransız Illişkileri Çerçevesinde Osmanlı Topraklarında Açılan Fransız Kültür Kurumları ve Bunların Meşruiyet Kazanması (19. Yüzyıl-20. Yüzyıl Başları)”, Ankara Üniversitesi Osmanlı Tarihi Araştırma ve Uygulama Merkezi Dergisi, 11 (2000), 708-709.

13 Yahya Akyüz, Türk Eğitim Tarihi (M.Ö. 1000- M. S. 2019), (Ankara: Pegem Akademi Yayınları, 2019), 175.

${ }^{14}$ Adnan Şişman, "Misyonerlik ve Osmanlı Devleti'nin Son Döneminde Kurulan Yabancı Sosyal ve Kültürel Müesseseler", Türkler Ansiklopedisi, 14, (Ankara: Yeni Türkiye Yayınları, 2002). 175.

15 Mehmet Tekin, "Geçmişte ve Günümüzde Hatay'da Eğitim”, Hatay'da Eğitim ve Kültür, (Ankara; Milli Eğitim Bakanlığı Yayınları, 1983), 72; Yaşar Demir, "Antakya'da Misyon ve Misyonerlik Faaliyetleri”, Akademik Bakış Dergisi, 32 (2012). 2, 6-11).

16 Yaşar Demir, a.g.m., 5.

17 Mesud Fani Bilgili, Manda idaresinde: Hatay Kültür Hayatı, (Antakya: Iktisat Basımevi, 1939), 38-39; Yusuf Duran, "iskenderun Sancağında Fransız Mandası (1920-1936)", (yüksek lisans tezi, Ankara Üniversitesi, 2007), 154-158.

18 Mesud Fani Bilgili, a.g.e., 22-24; Mehmed Tekin, a.g.m., 72; Yaşar Demir, a.g.m., 6-11.

19 Yaşar Demir, a.g.m., 9-10.
} 
mevkiinde yeni bir okul binası ve dispanser açmıştır. ${ }^{20}$ Okul Lazaristlerden sonra Cizvit misyonerleri tarafından kullanılmıştır. ${ }^{21}$ Bazı kaynaklarda ise okulun kuruluş tarihi 1930 olarak verilmiştir. ${ }^{22}$

Harita 1: Lazarist Misyonerlerinin Faaliyette Bulunduğu Akbez ve Kırıkhan Yerleşimleri

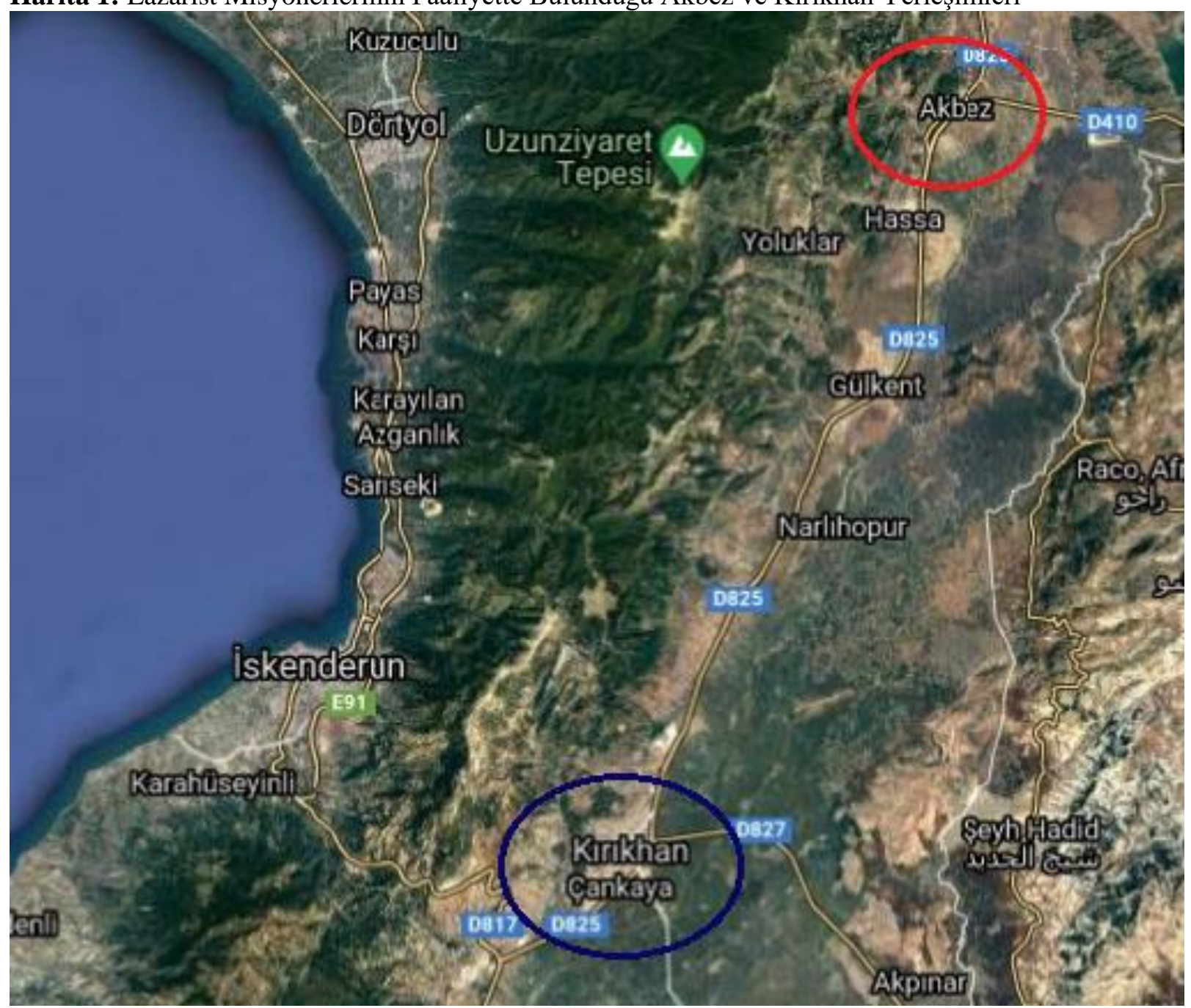

Kaynak: https://parselsorgu.tkgm.gov.tr/ Erişim Tarihi: 24.03.2021

\subsection{Mimari Özellikleri}

Kırıkhan ilçe merkezindeki yapı, 2904 Parsel'de bulunmaktadır. Kuzeyde Gürsel Sokak, doğuda Erciyes Sokak ve güneybatıda Oğuzlar Caddesinin çevrelediği bir alan içerisinde yer almaktadır. Yüksek kottaki yapıya ulaşım, Oğuzlar Caddesi üzerinden sağlanmaktadır.

20 Mesud Fani Bilgili, a.g.e., 23; Mehmed Tekin, a.g.m., 72; Yaşar Demir, a.g.m., 9-10.

21 Övgü Garbioğlıu, “Tanzimat’tan Cumhuriyet'e Hatay’da Kamu Yapıları” (yüksek lisans tezi, Mimar Sinan Güzel Sanatlar Üniversitesi, 2017), 51.

22 Şerife Yorulmaz, “Fransız Manda Yönetimi Döneminde İskenderun Sancağı (Hatay)’nın Sosyo-Ekonomik ve Siyasal Durumuna illişkin Bazı Kayıtlar (1918-1939)", Ankara Üniversitesi Atatürk Yolu Dergisi, 6/22 (1998), 244. 
Farkl1 kotlarda bir bodrum kat üzerine iki katlı olarak inşa edilen yapı, merkezde güneydoğu-kuzeybatı doğrultuda uzanan dikdörtgen planlı bir kilise ile bunu kuzeydoğu, kuzeybatı ve güneybatıda "U" şeklinde çevreleyen koridor ve dersliklerden oluşmaktadır (Çizim 1). İki kat yüksekliğinde ve tek mekândan ibaret olan kilisenin güneydoğu ucunda, yarım daire formlu apsis bulunmaktadır. Kilisenin duvarları, her iki katta da yan yana sıralı yuvarlak kemer açıklığı şeklindeki nişlerle hareketlendirilmiştir (Resim 1). Ancak, üst kattaki bazı kemerlerin sonradan kapatıldığının tespit edilmesi, özgün halinde açık olduğuna işaret etmektedir. Böylelikle kilisenin yanlarda, her iki katta da kemer dizileri ile koridorlara bağlantı sağladığ1 anlaşılmaktadır. Apsis, bir basamak ile zeminden yükseltilmiş ve sunak masasının olması gereken yere, muhdes kademeli beton platform eklenmiştir. Apsisin duvarlarında da nişler yer almakta olup, güneydoğu duvardaki kapı açıklı̆̆ından gerideki dikdörtgen mekâna geçiş sağlanmaktadır. Yapının göründüğü bazı eski fotoğraflarda mevcut olduğu anlaşılan bu mekânın duvarlarında pencere ve nişler bulunmaktadır (Resim 2). Mekânın işlevi tam olarak bilinmemekle birlikte, din görevlisine ait bir alan olarak kullanıldığ düşünülmektedir.

Çizim 1. Kırıkhan Ruhban Okulu Zemin ve Birinci Kat Planı
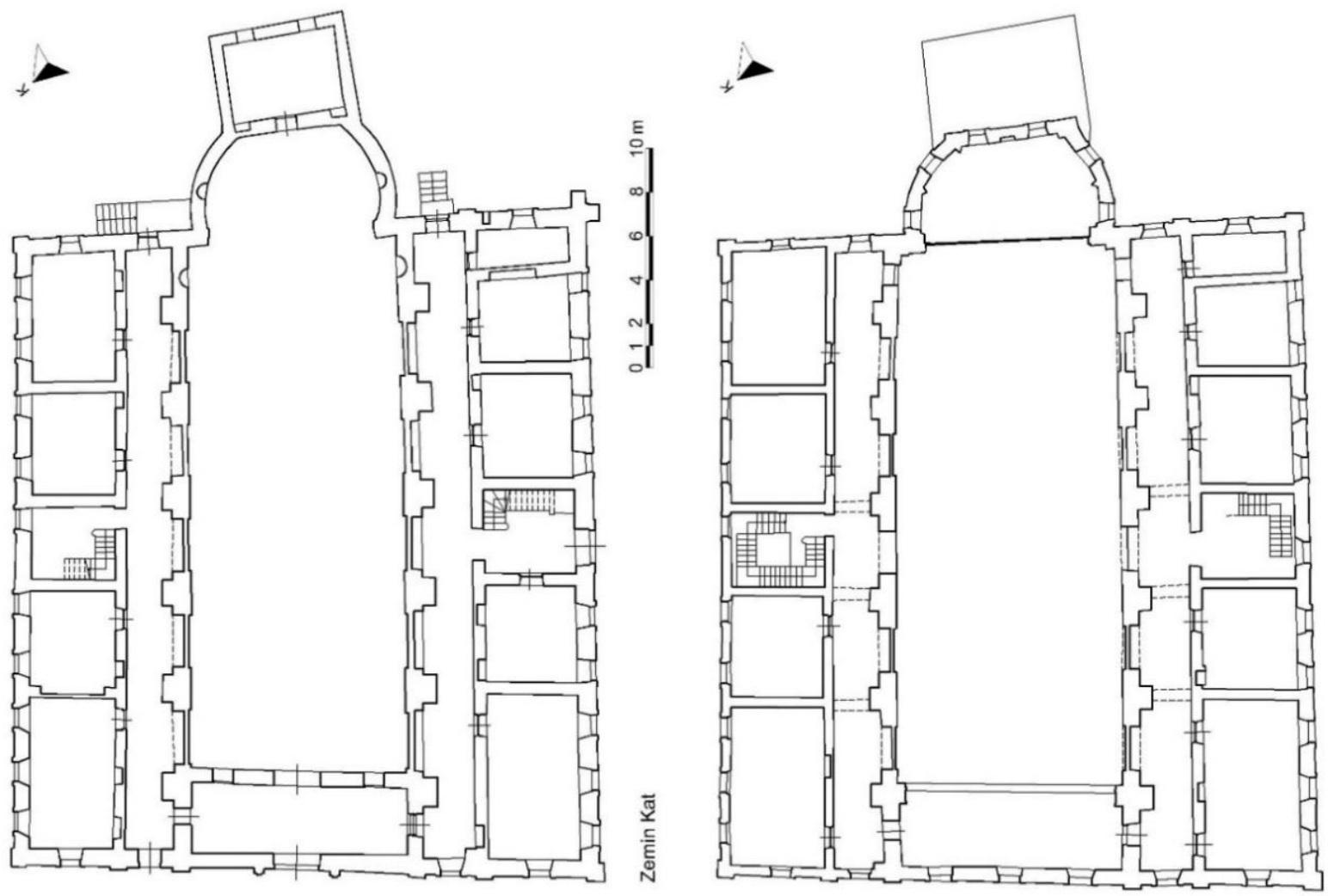

Kaynak: Hatay Kültür Varlıklarını Koruma Bölge Kurulu’ndan İşlenerek 
Resim 1. Yapının Kilise İç Mekânı

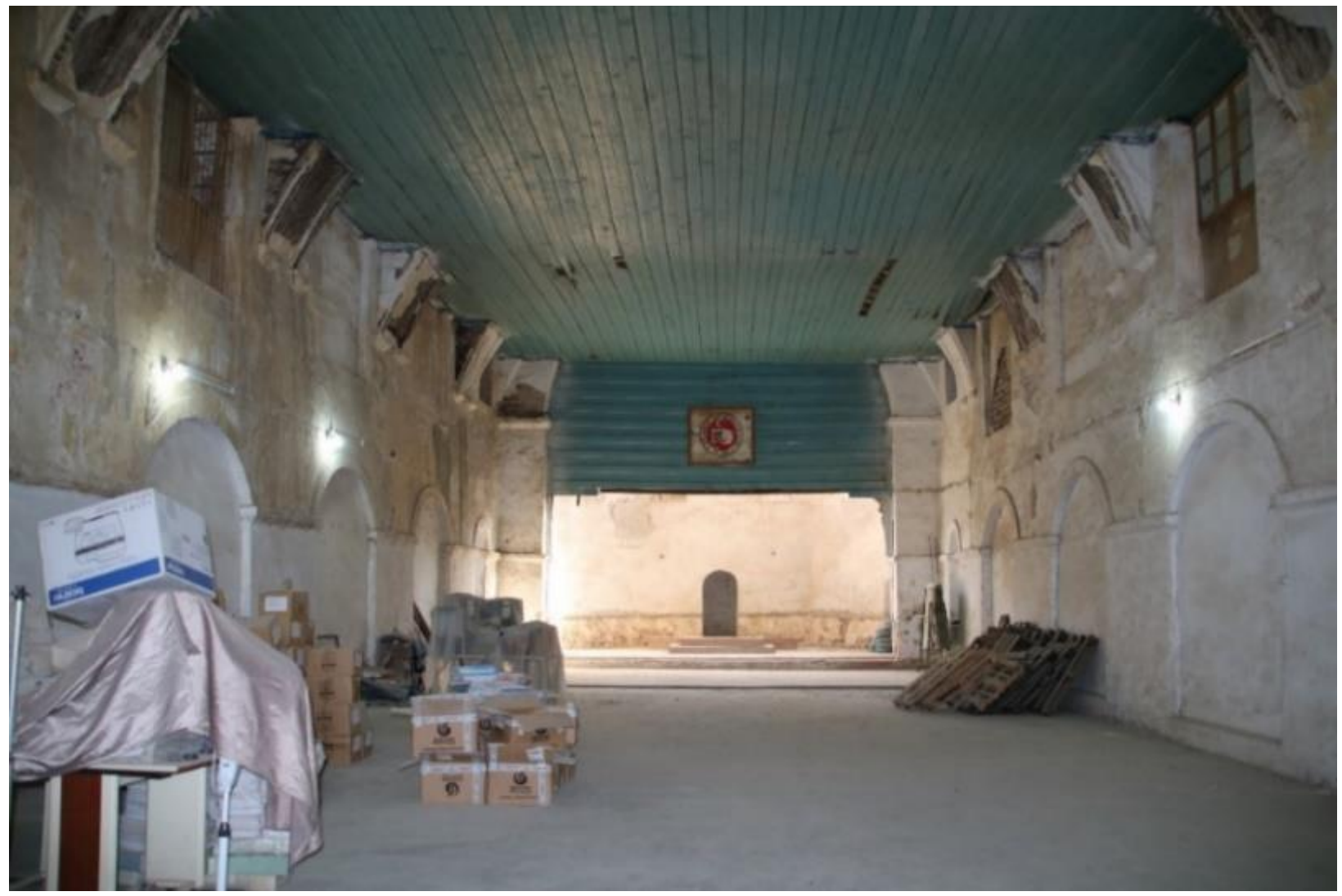

Kaynak: Servet Özkan-2019

Resim 2. Kırıkhan Ruhban Okulu'nun Tarihsiz Bir Fotoğrafı

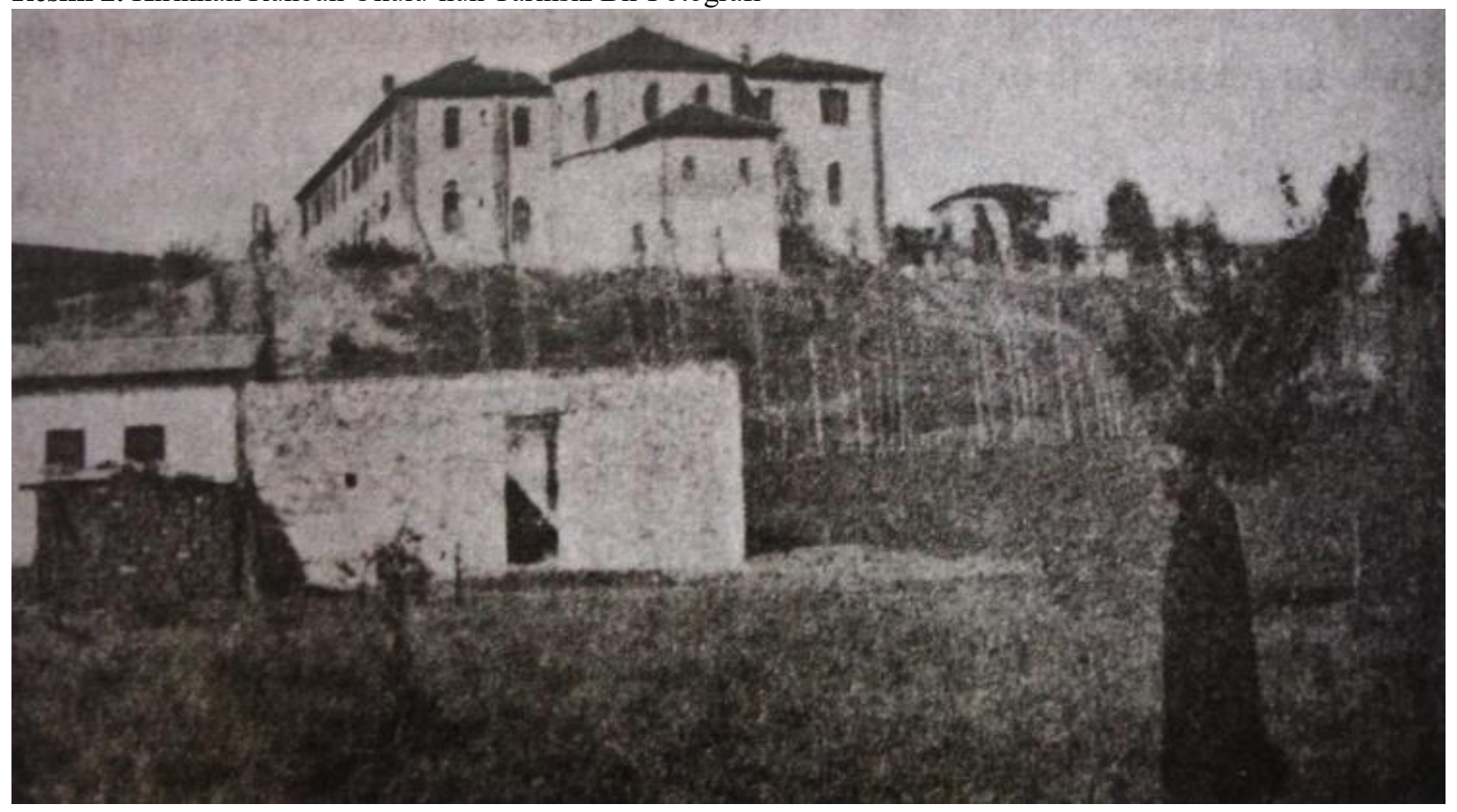

Kaynak: Hatay Kültür Varlıklarını Koruma Bölge Kurulu Arşivi 
Günümüzde yan kanatlarla herhangi bir bağlantısı bulunmayan kilise, kuzeybatı duvarda, ortadaki daha geniş ve yüksek olan üç kapı ile koridora açılmaktadır. Koridor, kuzeydoğu ve güneybatı duvarlardaki birer kapı ile yan kanatta yer alan diğer koridorlara bağlantı sağlamaktadır. Kuzeybatı duvarında ise yapının ana kapısı bulunmaktadır. Koridorun zemininde, üstü demir kapaklı, küçük kare bir açıklık yer almaktadır (Resim 3). Yapının rölöve raporunda, bu açıklığın bodrum katta yer alan papaz mezarına geçiş sağladığı belirtilmiştir ${ }^{23}$. Bodrum kat, zeminleri toprak dolgulu, duvarları moloz taşlarla örülmüş ve tonoz örtülü olan farklı ölçülerde birimlerden meydana gelmiştir (Resim 4).

Resim 3. Zemin Kat Kuzeybatı Koridorun Zeminindeki Kapaklı Açıklık

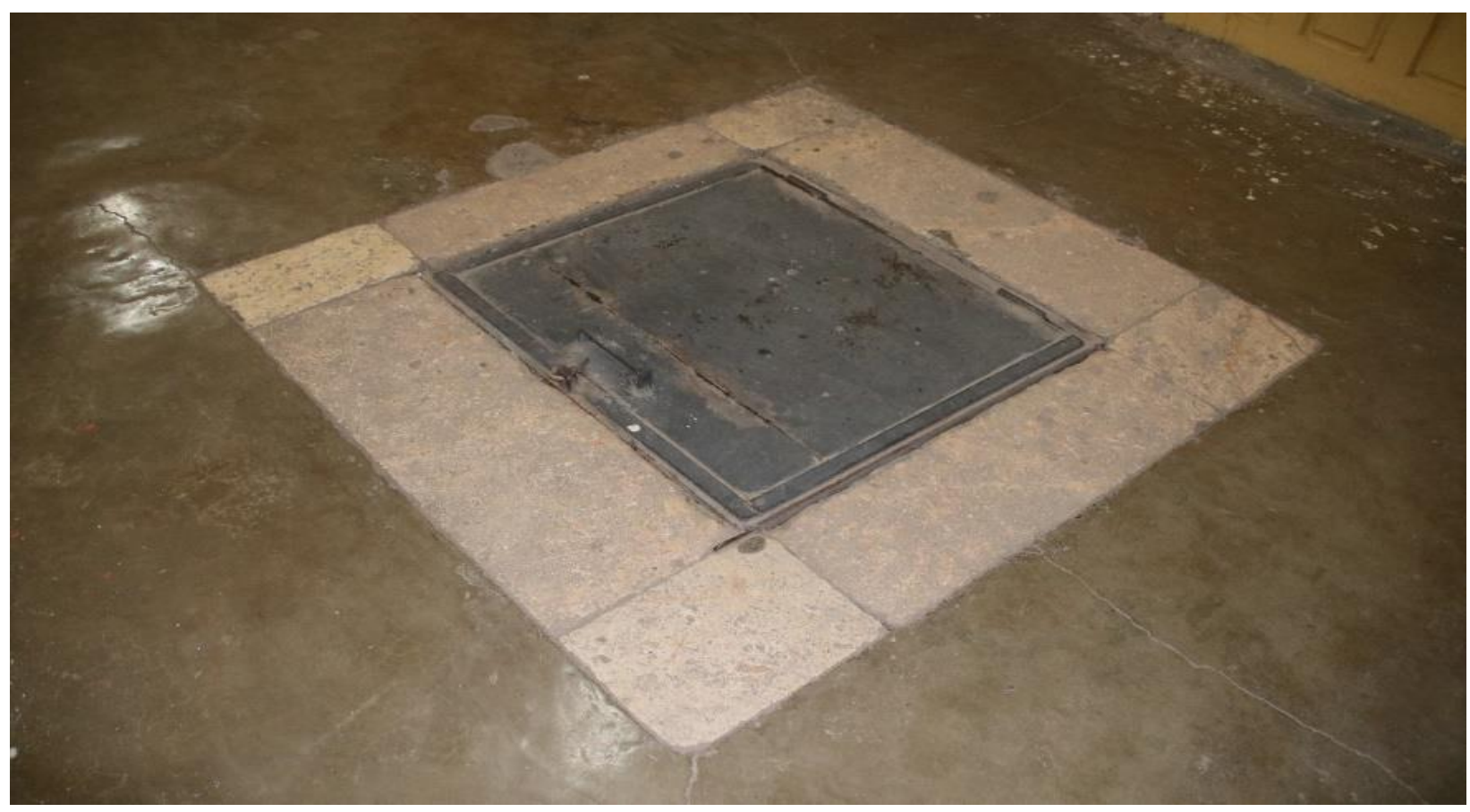

Kaynak: Servet Özkan-2019

Resim 4. Kırıkhan Ruhban Okulu'nun Bodrum Katındaki Bir Mekân

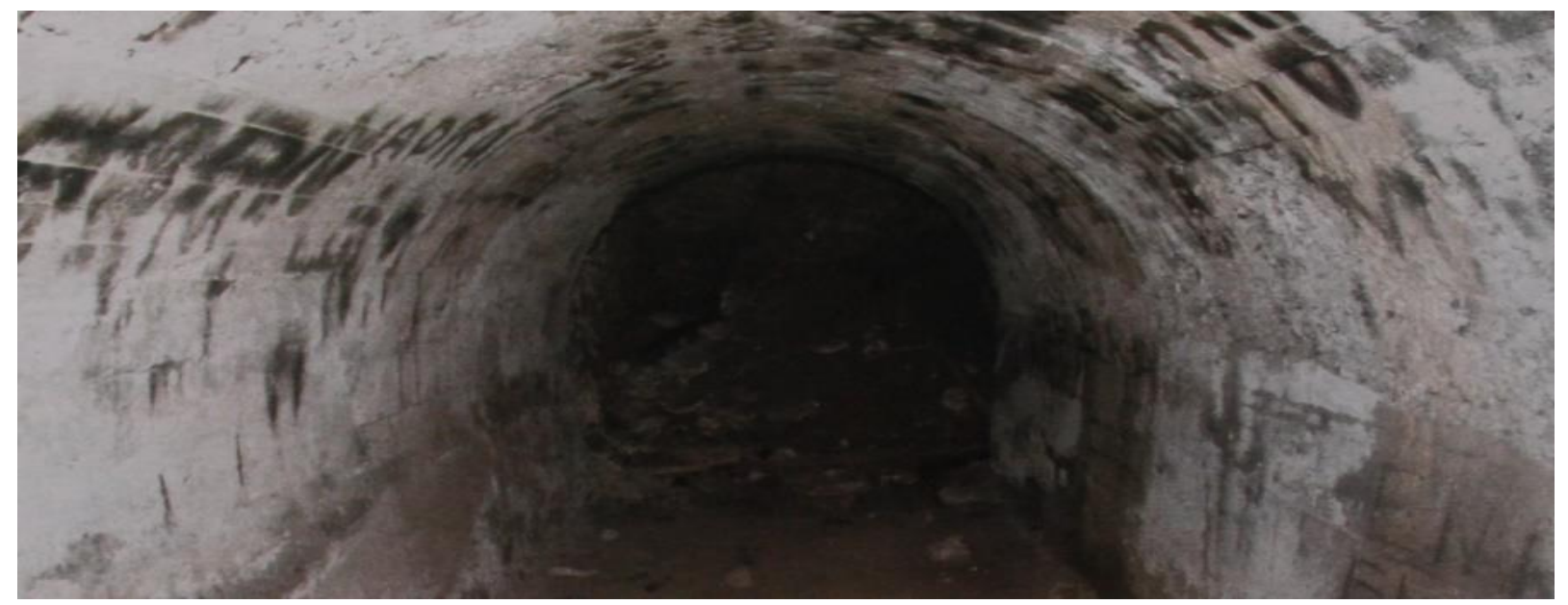

Kaynak: Hatay Kültür Varlıklarını Koruma Bölge Kurulu Arşivi 
Kilisenin iki yanındaki kanatlar, bitişik düzende sıralanmış derslikler ve depo olarak kullanılan ebatları farklı mekânlardan oluşmuştur (Resim 5). Mekânlar birer kapı ile koridorlara bağlantı sağlamaktadır. Bu koridorlar, duvar payelerine oturan yuvarlak kemerli geçişlerden meydana gelmiştir (Resim 6). Kuzeydoğu kanatta beş, güneybatı kanatta altı sıralı mekân yer almakta olup, bunlardan tam ortadakiler simetrik olarak yerleştirilmiş merdiven holüdür. Yapının birinci katında da, zemin kat planı tekrar edilmiştir. Zemin kat kuzeybatı koridorunun üstü, birinci katta bir balkon şeklinde kilisenin iç mekânına açılmaktadır.

Yapının beş adet ana kapısı bulunmakta olup, bunlardan ikisi kuzeybatı cephede yer almaktadır (Resim 7). Bu cephe merkezindeki geniş açıklık ana kapı, bunun kuzeyindeki kapı ise kuzeydoğu koridor kapısıdır. Güneybatı cephenin merkezinde, ikinci ana kapı açıklığı yer almaktadır (Resim 8). Güneydoğu cephede ise yan kanat koridorlarına ulaşım sağlayan birer kapı bulunmaktadır. Yapıdaki kot farkı nedeniyle kuzeybatı cephedeki mekânlara doğrudan ulaşım sağlanırken, güneydoğudakilere birkaç basamak merdivenle ulaşılmaktadır. Ayrıca, yapının güney köşesinde iki adet düz payandaya yer verilmiştir.

Resim 5. Yapının Zemin Kat Dersliği

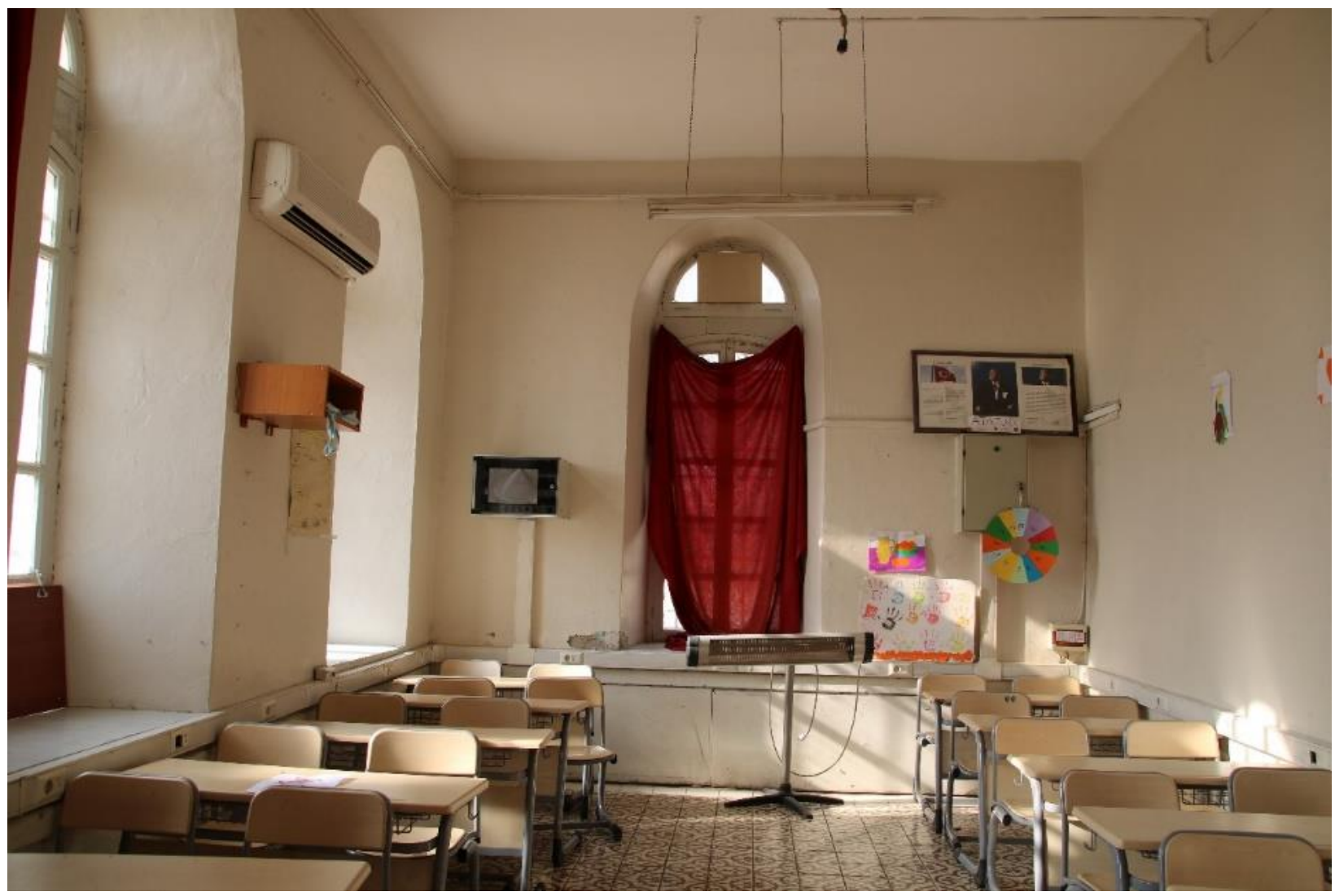

Kaynak: Servet Özkan-2019 
Resim 6. Yapının Zemin Kat Koridoru

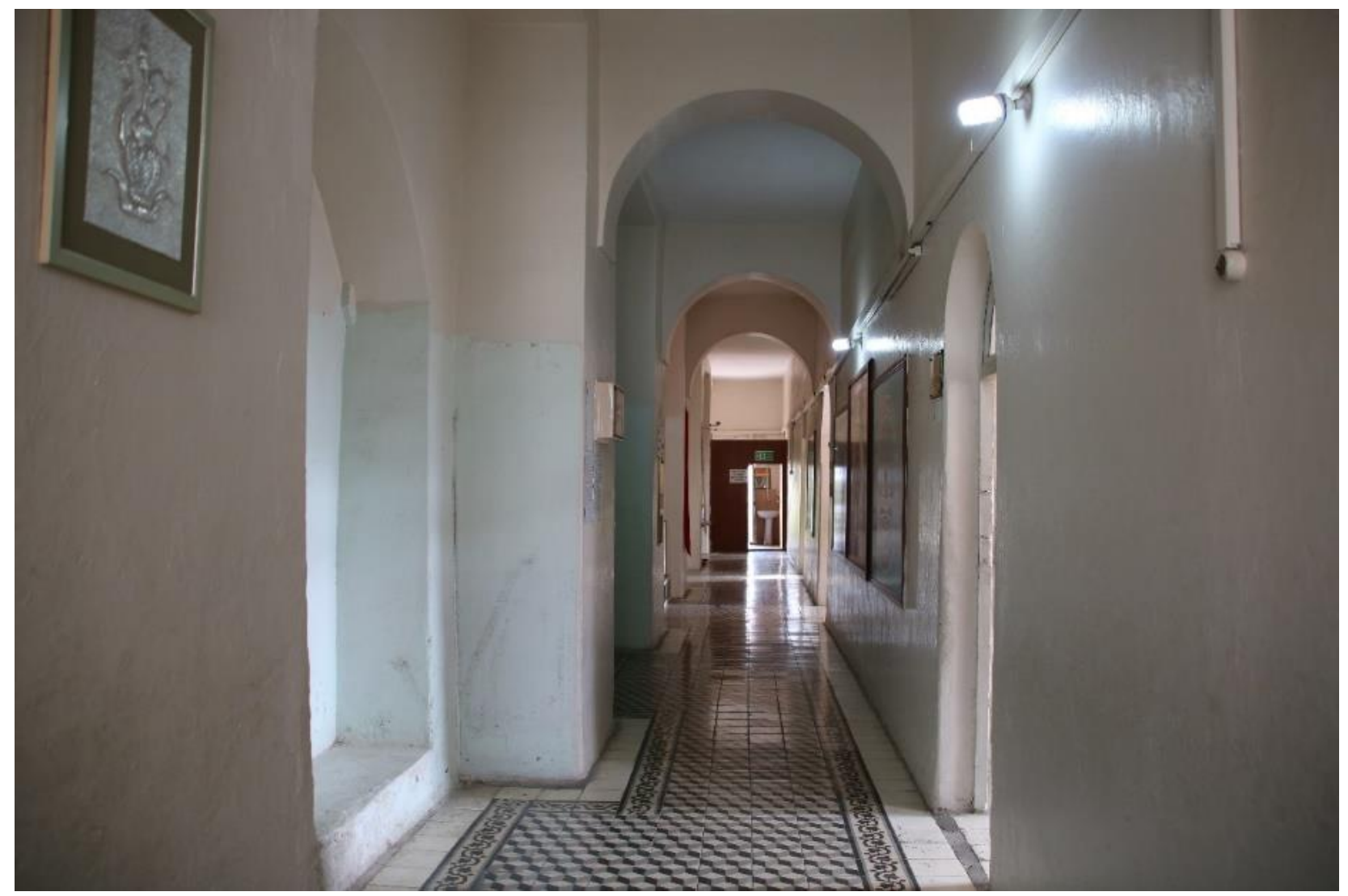

Kaynak: Servet Özkan-2019

Yapının kapı açıklıkları yuvarlak kemerlidir. Basık kemerli zemin kat pencere söveleri cephelerde dışa çıkıntı yapmaktadır. Söve üst köşeleri, iki yana boynuz şeklinde uzanmaktadır. Güneybatı ve kuzeybatı cephelerin zemin kat pencereleri farklı bir düzen göstermektedir. Buradaki pencerelerin hemen üstünde, yuvarlak kemer formlu küçük aydınlatma pencerelerine yer verilmiştir. Dış cephelerde büyük ve küçük pencere şeklinde algılanan bu tasarım, iç mekânda yuvarlak kemerli tek pencere olarak görünmektedir (Resim 5). Diğer cephelerde ise böyle bir uygulama bulunmamaktadır. Güneybatı cephede, ana girişin her iki yanında pencerelerle aynı formda olan, ancak açıklı̆̆ bulunmayan söve biçiminde düzenleme yer almaktadır. Birinci katta, dıştan basık kemerli olan pencereler içten düzdür. Bu katta da pencere sövelerinin üst köşeleri boynuz şeklinde bir form ile hareketlendirilmiştir. Yapının güneydoğu cephesindeki pencereler yuvarlak kemerli olup, kilise apsis pencereleri sivri kemerlidir (Resim 9,10). Yapıdaki bütün pencere açıklıkları, mekânların daha fazla aydınlatılmasına yönelik olarak, dıştan içe doğru verev olarak genişleyen bir tasarım sergilemektedir.

Moloz taş ve kesme taş malzeme ile inşa edilen yapının duvarları sıvalı ve boyalıdır. Mekânların zeminleri, beton şap ya da karo mozaik ile kaplıdır. Pencere ve kapılar ahşap doğramadır. Bazı mekânların kapıları ise sonradan dökme demir malzeme ile yenilenmiştir. Kilise tavanı geç dönemde ahşap malzeme ile kapatılmıştır. Apsis ise bağdadi tekniğinde yapılmış yıldız tonoz örtülüdür. Dökme mozaik merdivenler, demir korkuluklarla çevrelenmiştir.

Yapının süsleme öğelerini taş süsleme ve karo mozaik olarak iki gruba ayırmak mümkündür. Kuzeybatıdaki ana kapının iki yanında, cepheden dışa çıkıntı yapan taş kaideler bulunmaktadır. Kaidelerin üzerinde, başlıkları kabartma yaprak motifleri ile süslenmiş ikişer adet gömme sütun yer almaktadır (Resim 11). Sütunlar, üstte, üç boyutlu olarak algılanabilen üçgen alınlık şeklinde bir başlıkla sonlanmaktadır. 
Pencere sövelerinin üst köşelerinde uzanan boynuz şeklindeki süslemeleri de bu grupta değerlendirmek mümkündür. Yapının iç mekân zeminlerini süsleyen karolar ise bitkisel ve geometrik desenlerden meydana gelmiştir. Bitkisel motifli karolarda kıvrımlı dallar, yaprak ve çiçek motifleri, geometrik desenli karolarda ise yıldız, baklava, zikzak ve daireler tercih edilmiştir (Resim 12).

Bir dönem Kurtuluş Ortaokulu olarak hizmet veren yapı, günümüzde Halkeğitim Merkezi olarak kullanılmaktadır. Yapının bir bölümü bu amaç doğrultusunda aktif olarak kullanılmaktayken, kilisenin harap ve bakımsız durumda olduğu gözlemlenmiştir. Restorasyon projesi hazırlanarak Koruma Kurulu'na sunulan yapıda henüz restorasyon konusunda bir çalışma gerçekleşmemiştir.

Resim 7. Yapının Kuzeybatı Cephesi

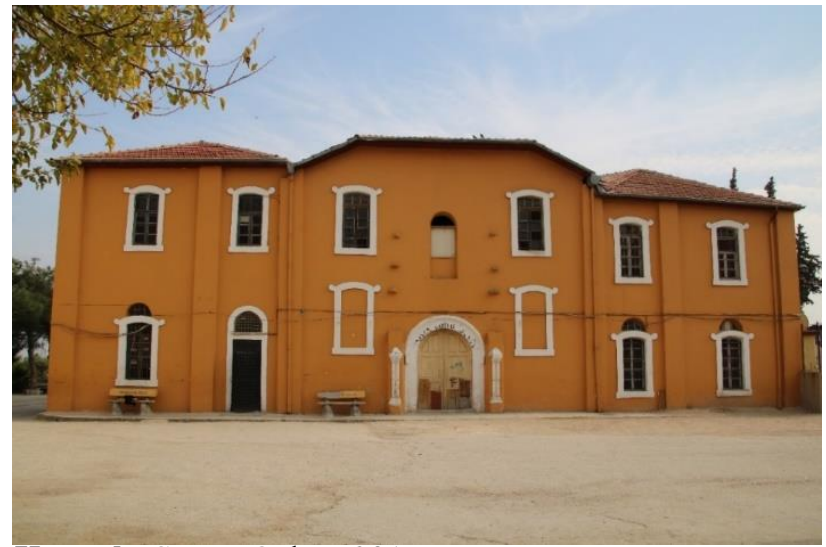

Kaynak: Servet Ozkan-2019
Resim 8. Yapının Güneybatı Cephesi

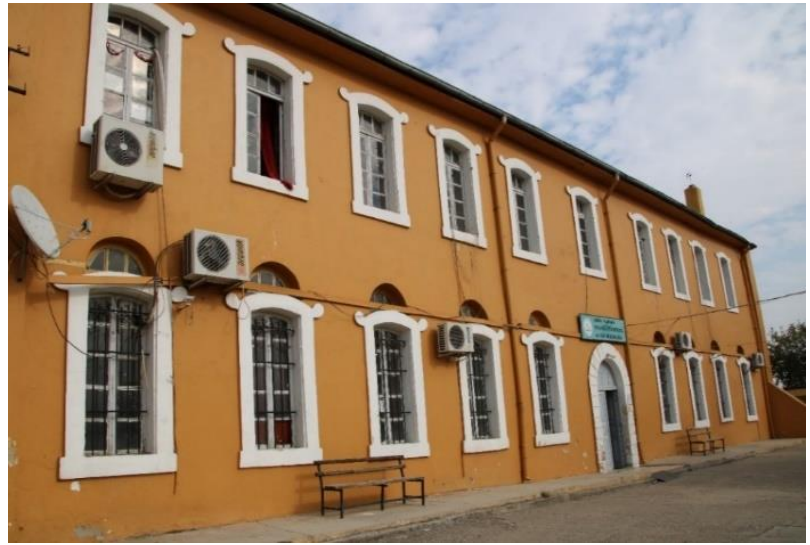

Resim 9. Yapının Apsis Cephesi

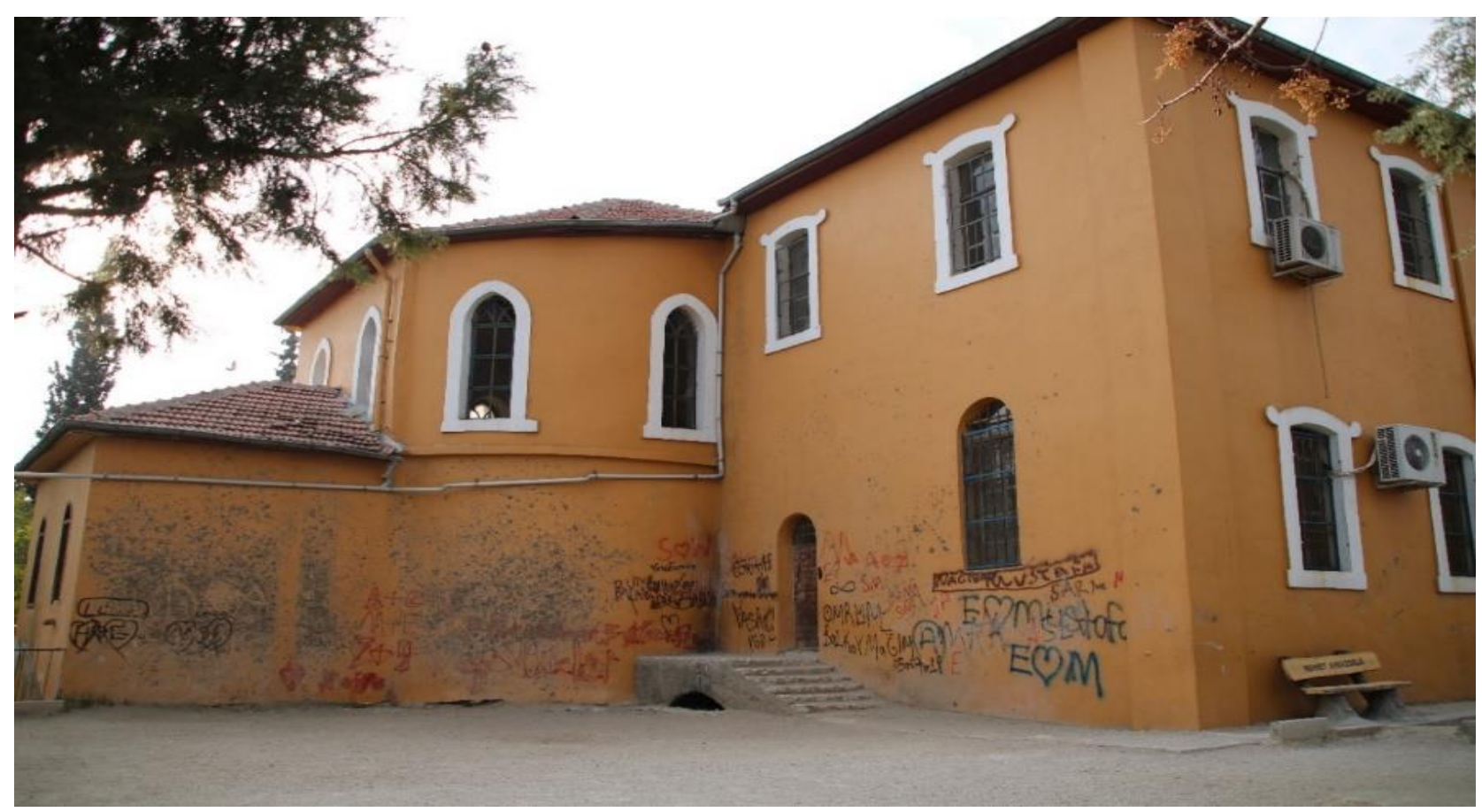

Kaynak: Servet Özkan-2019 
Journal of Ottoman Civilization Studies

NO. 12 (2021), 42-58

S. Özkan

Resim 10. Apsis Pencere Detay1

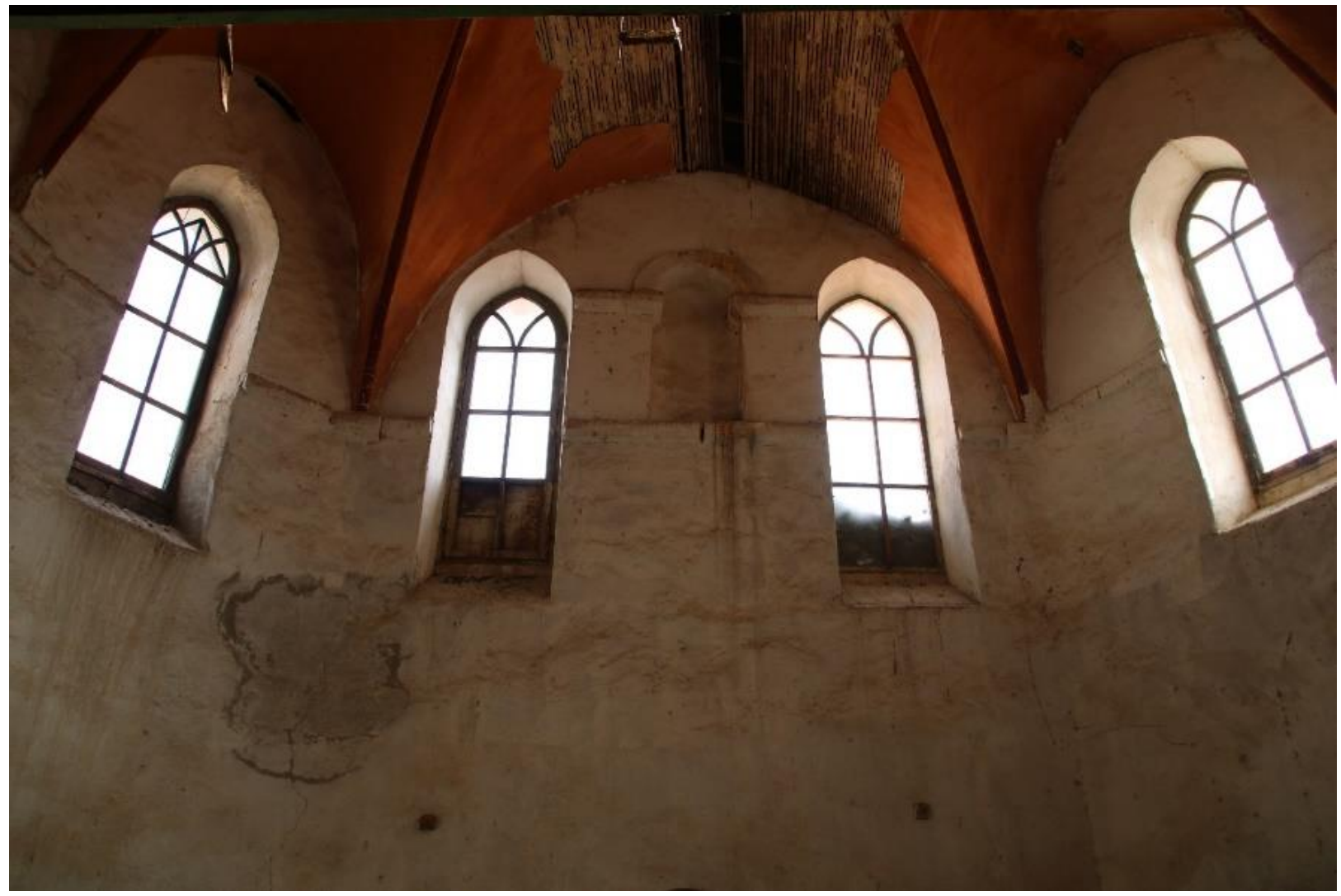

Kaynak: Servet Özkan-2019

Resim 11. Yapının Kuzeybatıdaki Ana Kapısı

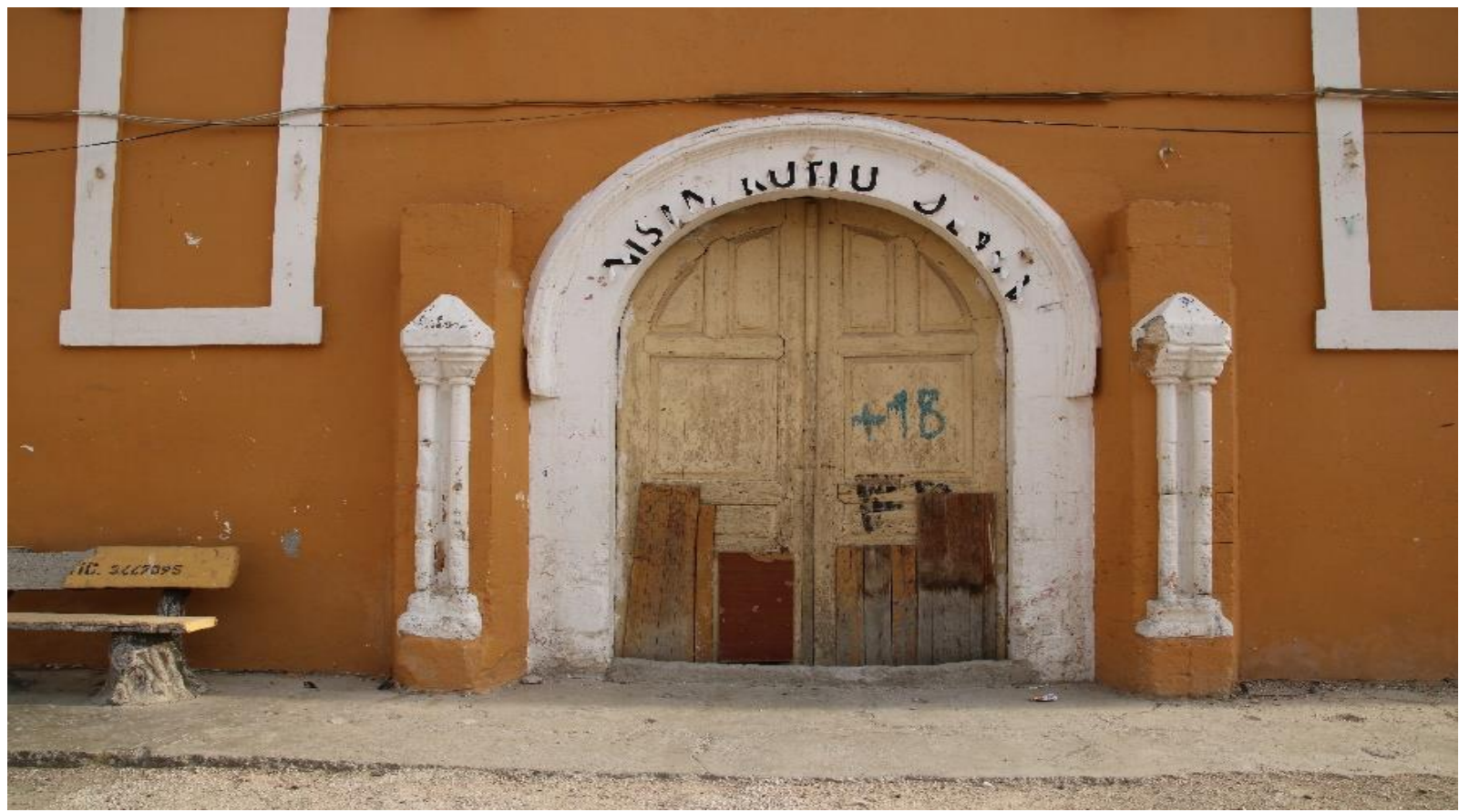

Kaynak: Servet Özkan-2019 
Resim 12. Yapının Zemin Karo Mozaikleri
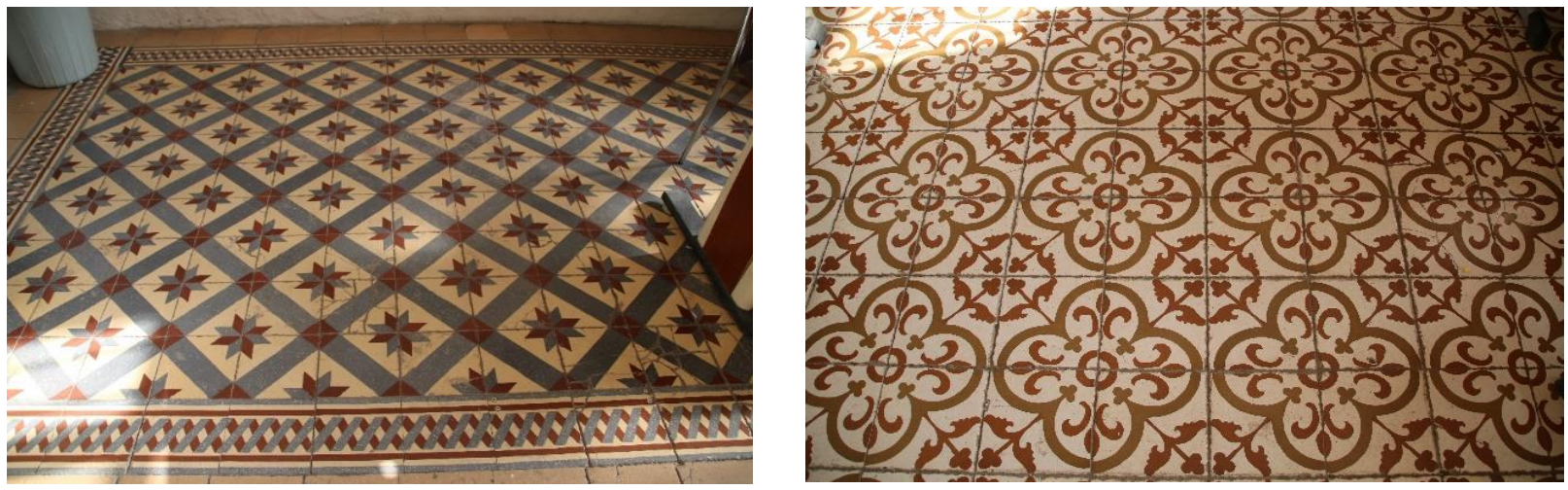

Kaynak: Servet Özkan-2019

\section{Karşılaştırma ve Değerlendirme}

Osmanlı Devleti sınırları dâhilinde açılmış Fransız eğitim kurumları, genellikle şehir merkezlerinde ya da merkeze yakın konumda inşa edilmiştir. Ayrıca, bir kiliseye bitişik veya kiliseye yakın olarak kurulan bu okulların konumlanmasında, ibadet mekânına ulaşım kolaylığı önemli bir faktör olarak karşımıza çıkmaktadır. Bu özellikleri ile Fransız okullarının adeta bir manastır yapısı olarak inşa edildiğini söylemek mümkündür. İstanbul Galata Saint Benoit Fransız Koleji (1783), Şişli Notre Dame de Sion Fransız Okulu (1856), Üsküdar İmmaculee Conception Fransız Okulu (1894), Haydarpaşa Sainte Euphemie Fransız Okulu (1895) ve İzmit St. Barbe Koleji (1895) kiliseye bitişik konumlarıyla; Galata St. Pierre Fransız Okulu (1854), Şişli St. Esprit Fransız Kız ve Erkek Okulları (1871) ve Kumkapı Assomption Fransız Koleji (1883) ise kiliseye yakın konumları ile dikkat çeken Fransız eğitim kurumlarına örnek gösterilebilir. Kırıkhan Ruhban Okulu ise plan kuruluşu ve okul-kilisenin konumlanışı açısından bu okullardan farklı bir tasarım sergilemektedir. Yapı, diğer Fransız eğitim kurumları gibi bir kiliseye yakın ya da bitişik olarak değil, kilise ve okul iç içe olacak şekilde birlikte tasarlanmıştır. Bir ibadet mekânını barındırması yönünden diğer Fransız okulları ile Kırıkhan örneği arasında bir bağlantıdan söz edilebilse de yapıya hâkim konumdaki kilisesi ve bunun etrafını saran derslikleri ile Kırıkhan Ruhban Okulu'nun farklı bir düzen gösterdiğini söylemek mümkündür.

Resim 13: Kiliseye Bitişik Konumlanan Fransız Okulu Örnekleri

(Haydarpaşa St. Euphemie Fransız Okulu ve İzmit St. Barbe Fransız Koleji)
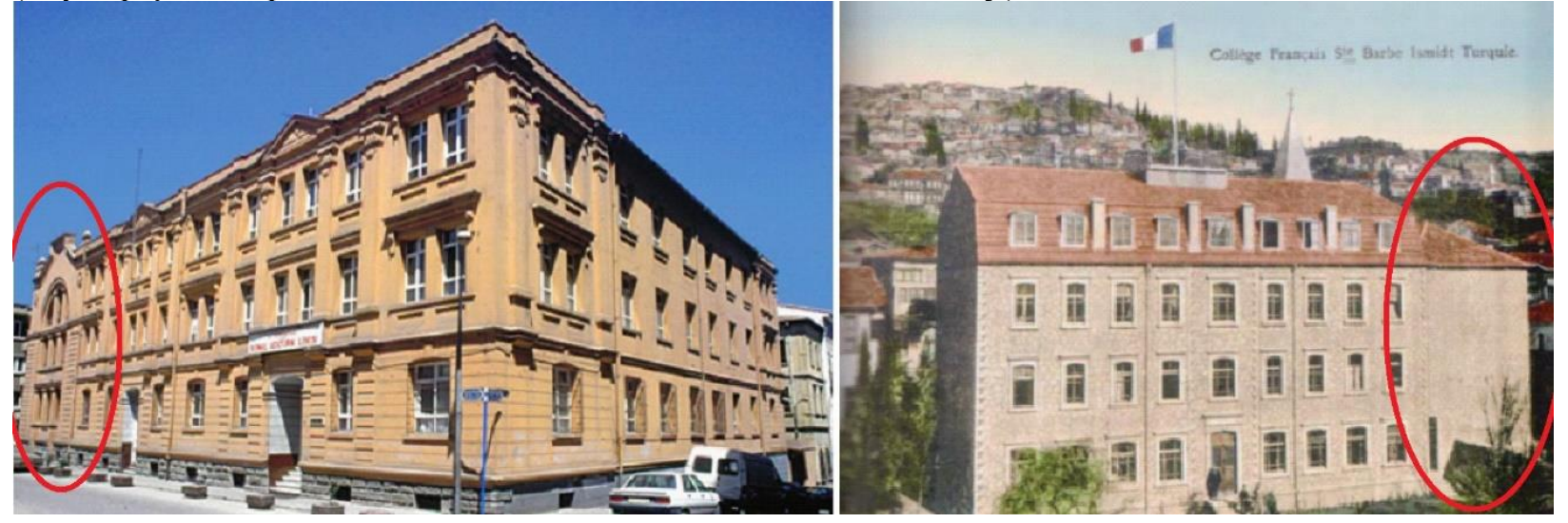

Kaynak: Semavi Eyice ve Bahadır Bozdağ 
Okulun plan kuruluşu, simetrik bir tasarımı yansıtmaktadır. Kilise etrafındaki koridorlar ve koridorlara açılan mekânlar, iki katta da bu anlayışı devam ettirmektedir. Yapıya hâkim konumda olan kilisenin yanlardaki koridorlara kemer dizileri ile bağlanması, üç nefli kiliseleri akla getirmektedir. Okulun inşa amacına ithafen, plan kuruluşunun bu şekilde tasarlandığını söylemek mümkündür. Ayrıca, yapının plan düzeni ile Anadolu'nun en önemli eğitim kurumlarından olan, iki katlı, revaklı ve açık avlulu Selçuklu Medreselerini andırdığı söylenebilir. Buradaki tek fark, ortada açık avlu yerine bir kilise bulunmasıdır.

Yapıda mekânların işılevsel dağılımına baktığımızda, derslikler, ibadet mekânı ve depo olarak kullanılan birimler dışında tanımlayabileceğimiz bir mekân bulunmamaktadır. Bir manastır şeklinde kurulmuş olan bu okulda, öğrenci yatakhanesi ve yemekhane işlevi gören bir alanın yer almadığı görülmektedir. Bu ihtiyaçlar için okul ile aynı avluyu paylaşan bir başka yapı olduğu, ancak günümüze ulaşmamış olabileceği düşünülmektedir. Zira kilise-okul yapısı içerisindeki mekânların küçük ölçülerde kare ya da dikdörtgen birimler olması, bu ihtiyaçlara cevap verebilme ihtimalini azaltmaktadır.

Yapının cephe tasarımında da kendi içinde bir simetri anlayışından söz edilebilmektedir. Kuzeybatı ve güneybatı cephelerin zemin ve birinci kat pencereleri birbirlerinden farklı bir tasarımı yansıtsa da sövelerinin vurgulanması, üst köşelerdeki boynuz biçimli süslemeleri ile uyumlu bir dizilime sahip olduğu görülür. Diğer Fransız okullarında veya başka yapılarda karşılaşmadığımız boynuz şeklindeki süslemelerin yapıya özel bir tasarım oluşturduğunu söylemek mümkündür. Ana kapının yer aldığı kuzeybatı cephede, orta bölüm yan kanatlardan daha yüksek tutularak üçlü bir düzen oluşturulmuştur. Ayrıca ana kapı, iki yandaki gömme payeleri, giriş üstündeki penceresi ile cephede vurgulanmıştır. Cephede giriş bölümünün ön planda olmasi pek çok Fransız okulunda karşımıza çıkan bir düzenlemedir. Buna örnek olarak verilebilecek olan İstanbul Sainte Pulchérie Fransız Okulu (1846) (Resim 14), İstanbul Saint Vincent Fransiz Okulu (1883), İstanbul Saint Michel Fransız Koleji (1886) ve Paris Pensionnat de Passy (1895) gibi bazı eğitim kurumlarında, giriş cephesinin plaster, balkon, saat ve alınlık gibi ögelerle vurgulandığı görülmektedir. ${ }^{24}$ Ayrıca, Fransa desteği ile açılan Galatasaray Mekteb-i Sultanisi de (1868) bu tasarımı yansıtmaktadır. Ancak bu yapılar, Kırıkhan Ruhban Okulu'nun daha büyük ve anıtsal örnekleri olarak karşımıza çıkmaktadır.

Resim 14. Sainte Pulchérie Fransız Okulu

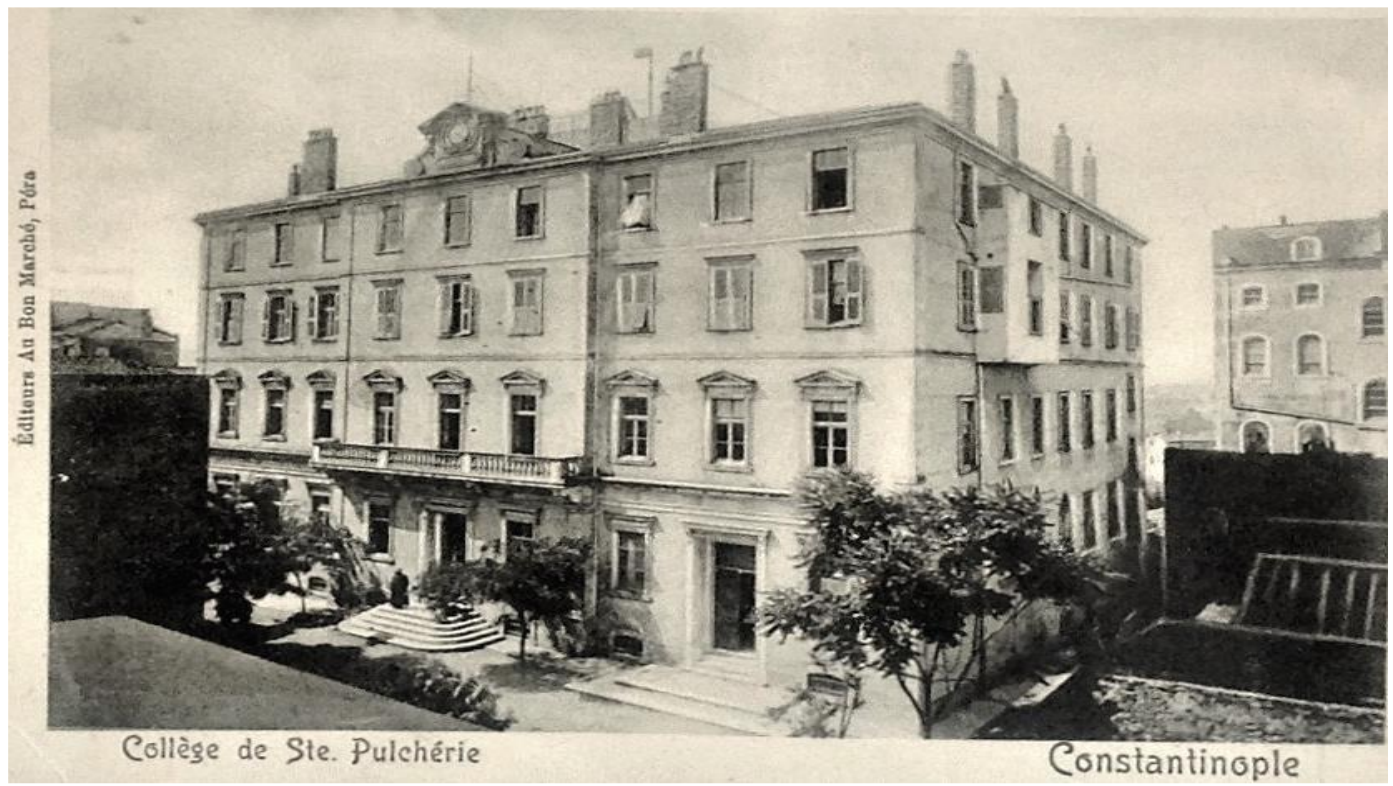

Kaynak: Zübeyde Gözde Kutlu

24 Zübeyde Gözde Kutlu, “19.Yüzyıldan Günümüze İstanbul’da Fransız Okul Yapıları, (Doktora tezi, İstanbul Teknik Üniversitesi, 2018), 294. 
Kırıkhan Ruhban Okulu'nda giriş cephesinin öne çıkarılma sebeplerinden biri de yap1 merkezinde konumlanan kiliseyi vurgulama isteğidir. Bu nedenle iki yandaki süslemeli gömme payeler ile vurgulanan ana kapı ve yapının eski resimlerde kapı üstünde yer alan haç işareti, ibadet mekânın dış cephedeki yansıması olarak karşımıza çıkmaktadır (Resim 15). Bu özelliği ile yapı, kiliselerin giriş cephelerinde görülen anıtsal düzenin oldukça minyatür bir örneğidir. Böylece apsis cephesinde sivri kemerli pencere açıklıkları, kuzeybatı cephede ise üçlü düzen gösteren giriş bölümü ile vurgulanan kilisenin, yapının dış cephe tasarımında etkin rol oynadığı söylenebilir. Bazı Amerikan eğitim kurumlarında da bu düzenlemenin görüldüğü örneklere rastlanmaktadır. Tarsus Amerikan Koleji Sticker Hall (1911) binasında, yapının birinci katındaki şapele açılan ana kapı; silmeler, plasterler ve üçgen alınlık ile anıtsal hale getirilerek, ibadet mekânına cephede vurgu yapıldığı anlaşılmaktadır. Ayrıca şapelin duvarlarında, ortadaki daha geniş ve yüksek olmak üzere üçüz sivri kemerli pencerelere yer verilerek vurgu arttırılmıştır.

Kırıkhan Ruhban Okulu'nda koridor ve dersliklerin zemininde gördüğümüz geometrik ve bitkisel motifli karo mozaikler, 19. yüzyıl ikinci yarısı ile 20. yüzyıl başlarında inşa edilen eğitim kurumlarında sıklıkla tercih edilmiştir. İstanbul Saint Benoit Fransız Koleji (1783), İstanbul Immaculée Conception Fransız Okulu (1894), Sainte Euphémie Fransız Okulu (1895), Manisa Akhisar Or Yehuda Tarım Okulu (19. yy. son çeyreği ) ve Tarabya Rum İlkokulu (19. yy. sonu ) zemin döşemesinde karo mozaik kullanılan okullara örnek gösterilebilir (Resim 16) ${ }^{25}$ Bununla birlikte, Fransız manda döneminde Hatay sınırları dâhilinde inşa edilmiş kamu binası, konut ve otel gibi çeşitli yapı türlerinde karşımıza çıkan karoların, Fransızlar tarafından sevilerek kullanıldığını söylemek mümkündür. ${ }^{26}$

Resim 15. Kırıkhan Ruhban Okulu'nun Tarihsiz Bir Fotoğrafı

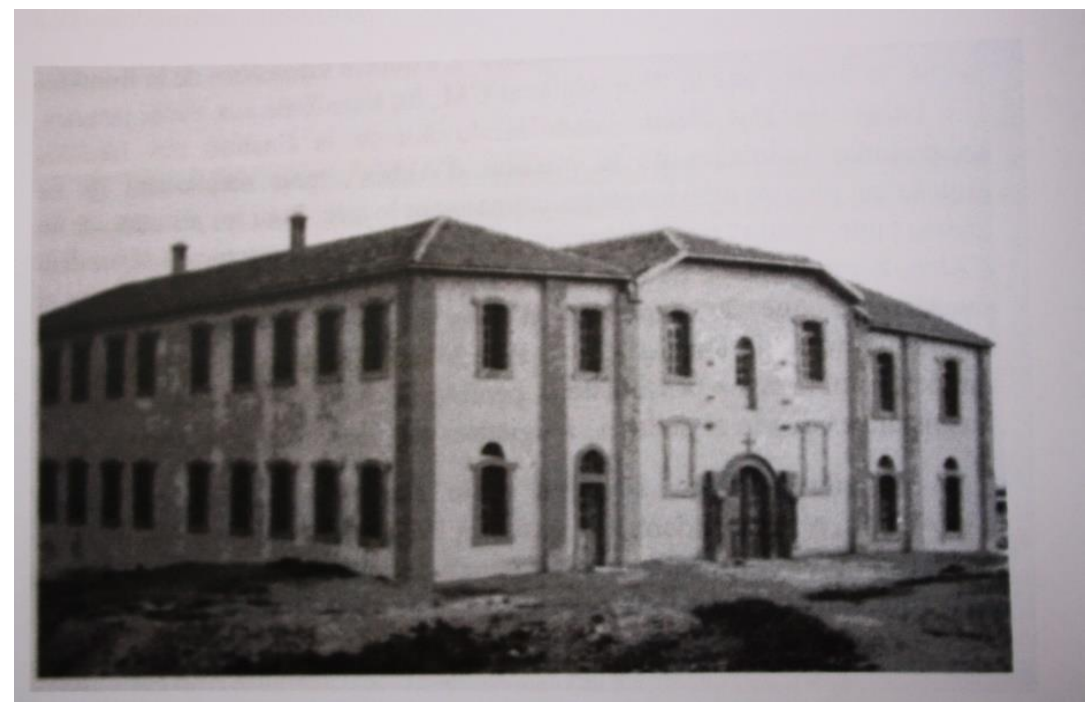

Kaynak: Hatay Kültür Varlıklarını Koruma Bölge Kurulu Arşivi

\footnotetext{
${ }^{25}$ Engin Aktürk, "Osmanlı Döneminde Anadolu ve Trakya Topraklarında Yahudi Cemaati Tarafından Kurulan Tarım Okulları ve Akhisar Or Yehuda Tarım Okulu Örneğinin Mimari İncelemesi”, (Yüksek lisans tezi, Mimar Sinan Güzel Sanatlar Üniversitesi, 2012), 91; Tuğçe Kıvrak, "Tarabya Rum Illkokulu Restorasyon Projesi”, (Yüksek lisans tezi, İstanbul Teknik Üniversitesi, 2016), 27; Zübeyde Gözde Kutlu, a.g.t., 141, 266, 274.

26 İnci Aslanoğlu, "Fransız İşgal ve Manda Döneminde İskenderun Sancağı: Kentsel ve Mimari Değişimleriyle İskenderun”, Antakya ve Kırıkhan Kazaları, Ortadoğu'da Osmanlı Dönemi Kültür İleri Uluslar Arası Bilgi Şöleni Bildirileri, I, (Ankara; Atatürk Kültür Merkezi Başkanlığı Yayınları, 2001) 93-94; F. Mine Temiz, "XX. Yüzyıl Başlarında Antakya'da Yeni Mimari Oluşumlara İki Örnek: Gündüz Sineması ve Adalı Evi", X. Ortaçağ-Türk Dönemi Kazıları ve Sanat Tarihi Araştırmaları Sempozyumu Bildirileri (Prof. Dr. H. Örcün Barışta'ya Armağan), Ankara: Gazi Üniversitesi Yayınları, 2009), 689; F. Mine Temiz - Emre Kolay, "Fransız İşgali Altındaki Antakya’nın Değişen Mimari Çehresine Bir Örnek: Saray Caddesi Kuseyri Binası", Hatay (Anavatana Katılışının 80. Yıl Armağanı, (ed. Ahmet Gündüz, Haydar Çoruh, Süleyman Hatipoğlu), (İstanbul: Hiper Yayın, 2019), 292.
} 
Resim 16. İstanbul Saint Louis Fransız Okulu ve Tarabya Rum İlkokulu Zemin Karoları
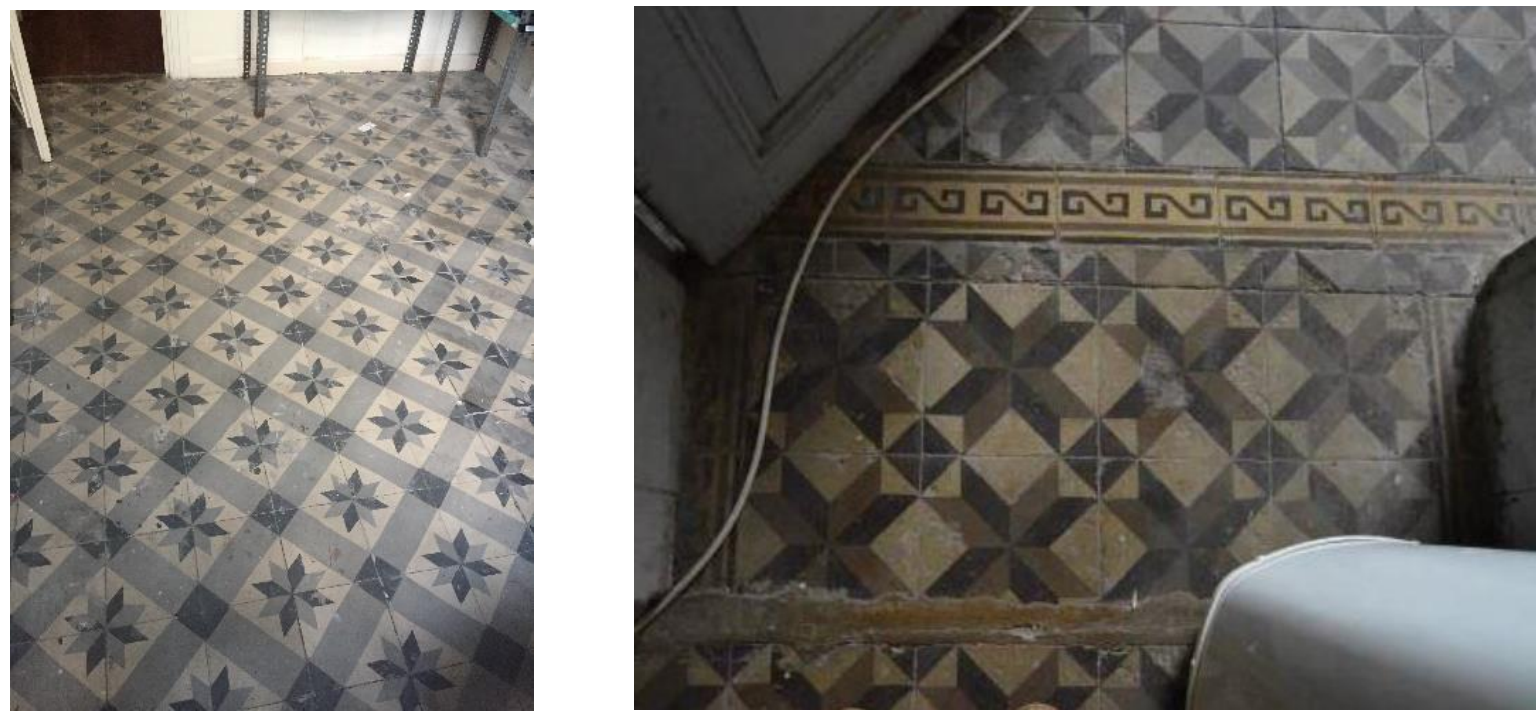

Kaynak: Zübeyde Gözde Kutlu ve Tuğçe Kıvrak

\section{Sonuç}

Bir toplumun gelişmesinde ve ilerlemesinde en temel unsurlardan biri olan eğitim, aynı zamanda bir devletin dini, siyasi, ideolojik hedeflerini gerçekleştirmede önemli bir faktördür. Bu önemin farkında olan Batılı devletlerin, eğitim konusunda daha yavaş bir ilerleme kaydeden Osmanlıyı dikkatlerinden kaçırmadığı ve eğitim kanalıyla Osmanlı topraklarında misyonerlik faaliyetleri yürüttüğü görülmektedir. Özellikle 19. yüzyılda yoğunlaşan misyonerlik çalışmaları, 20. yüzyıl başlarında da devam etmiş ve Osmanlı sınırları dahilinde adeta bir eğitim ağı oluşmuştur. İstanbul ve Anadolu'nun pek çok yerinde yoğun olarak sürdüren misyonerlik çalışmalarının önemli noktalarından biri olan Hatay, çoğunlukla Fransız misyoner gruplarının çalışma alanı olmuştur. Fransız manda hakimiyeti döneminde artan bu çalışmaların günümüzdeki yansımalarından biri olan Kırıkhan Ruhban Okulu, konum, simetri ve düzen gibi özellikleri ile diğer Fransız eğitim kurumlarına paralel bir gelişim göstermektedir. Ancak, bir okul-kilise olarak tasarlanmış planı ile diğer okullardan ayrılmakta ve ünik bir örneği temsil etmektedir. Bu tasarımda, yapının çekirdeğini oluşturan ve hem plan hem de cephe biçimlenişi açısından yapıya hakim konumda olan kilisenin büyük payı bulunmaktadır. Katolik inancı gereği ibadet mekanına yakınlık, Fransız okullarının kuruluşunda önemli bir faktör olarak karşımıza çıkmakta ve bu nedenle okulların kiliselere yakın konumda inşa edildiği görülmektedir. Bu özelliği ile adeta birer manastır olarak kurulan Fransız okulları, Kırıkhan örneğinde okul ve kilisenin içiçe inşa edilmesiyle özel bir tasarım kazanmış, ibadet ve eğitim tek yapı bünyesinde birleştirilmiştir. Bu özellikleri ile okulun, özellikle Fransız misyoner eğitim kurumları ile ilgili yapılacak yeni araştırmalara zemin hazırlayacağı düşünülmektedir. 


\section{Kaynakça}

Akyüz, Yahya. "Cevdet Paşa'nın Özel Öğretim ve Tanzimat Eğitimine İlişkin Bir Layihası”. Ankara Üniversitesi Osmanlı Tarihi Araştırma ve Uygulama Merkezi Dergisi, 3 (1992): 85-114.

Akyüz, Yahya. Türk Eğitim Tarihi (M.Ö. 1000- M. S. 2019. Ankara: Pegem Akademi Yayınları, 2019.

Anonim (1977); Özel Eğitim Kurumlar1, Türk Ansiklopedisi, XXVI (Ankara. MEB Yayınları), ss. 296-317.

Aktürk, Engin. "Osmanlı Döneminde Anadolu ve Trakya Topraklarında Yahudi Cemaati Tarafından Kurulan Tarım Okulları ve Akhisar Or Yehuda Tarım Okulu Örneğinin Mimari İncelemesi”. Yüksek lisans tezi, Mimar Sinan Güzel Sanatlar Üniversitesi, 2012.

Arıkan, Zeki. "Yirmisekiz Çelebi Mehmed Efendi”. İslam Ansiklopedisi, 43 (İstanbul 2013), ss. 551-552.

Aslanoğlu, İnci. "Fransız İşgal ve Manda Döneminde İskenderun Sancağı: Kentsel ve Mimari Değişimleriyle İskenderun, Antakya ve Kırıkhan Kazaları”, Ortadoğu'da Osmanlı Dönemi Kültür İzleri Uluslar Arası Bilgi Şöleni Bildirileri, I (2001): 89-96.

Ayhan, Halis. "Batılılaşma”, İslam Ansiklopedisi. 5 (İstanbul 1992), ss.158-162.

Bilgili, Mesud Fani. Manda İdaresinde: Hatay Kültür Hayatı. Antakya: İktisat Basımevi, 1939.

Bozdağ, Bahadır. "Kocaeli'de 19 YY. Fransız Misyoner Okullarının İzmit St. Barbe Koleji Örneğinde Koruma Önerisi”. Yüksek lisans tezi, Mimar Sinan Güzel Sanatlar Üniversitesi, 2019.

Demir, Yaşar. Antakya'da Misyon ve Misyonerlik Faaliyetleri, Akademik Bakış Dergisi, 32 (2012): 1-19.

Duran, Yusuf. İskenderun Sancağında Fransız Mandası (1920-1936). Yüksek lisans tezi, Ankara Üniversitesi, 2007.

Eren, Ahmet Cevat. Tanzimat Fermanı ve Dönemi. İstanbul: Derin Yayınları, 2007.

Eryılmaz, Bilal (2017); Tanzimat ve Yönetimde Modernleşme, İşaret Yayınları, İstanbul.

Eyice, Semavi. “Haydarpaşa”, İslam Ansiklopedisi, 17 (İstanbul 1998), ss. 36-41.

Garbioğlu, Övgü. “Tanzimat'tan Cumhuriyet'e Hatay’da Kamu Yapıları”. Yüksek Lisans Tezi, Mimar Sinan Güzel Sanatlar Üniversitesi, 2017.

Haydaroğlu, İlknur. “Osmanlı İmparatorluğu’nda Yabancı Okullar”, Türkler, 14 (Ankara 2002), ss. 181-188.

İhsanoğlu, Ekmelleddin. "Osmanlıda Eğitim ve Bilim Müesseseleri”, (ed. Ekmelleddin İhsanoğlu) Osmanlı Medeniyeti Tarihi, 1 (1999): 223-361.

Kılıç, Remzi. “Misyonerlik ve Türkiye’ye Yönelik Misyoner Faaliyetleri”, TÜBAR, 19 (2006): 327-342.

Kırıkhan Ruhban Okulu Rölöve (Belgeleme) Raporu (2012). Hatay Kültür Varlıklarını Koruma Bölge Kurulu Müdürlüğü Arşivi.

Kıvrak, Tuğçe. "Tarabya Rum İlkokulu Restorasyon Projesi”. Yüksek lisans tezi, İstanbul Teknik Üniversitesi, 2016.

Kutlu, Zübeyde Gözde. “19.Yüzyıldan Günümüze İstanbul'da Fransız Okul Yapıları”. Doktora tezi, İstanbul Teknik Üniversitesi, 2018.

Ortaylı, İlber. İmparatorluğun En Uzun Yüzyılı, İstanbul: İletişim Yayınları, 1995.

Şişman, Adnan. "Galatasaray Mekteb-i Sultanisi”, İslam Ansiklopedisi, 13 (İstanbul 1996), ss. 323-326.

Şişman, Adnan. "Misyonerlik ve Osmanlı Devleti'nin Son Döneminde Kurulan Yabanc1 Sosyal ve Kültürel Müesseseler", Türkler Ansiklopedisi, 14 (Ankara 2002): ss. 173-180. 
Taş, Tülün. “19. Yüzyılda Anadolu’da Katolik Misyonerlerin Eğitim Alanındaki Faaliyetleri”, Yüksek lisans tezi, Erciyes Üniversitesi, 2006.

Tanör, Bülent. “Anayasal Gelişmelere Toplu Bir Bakış”, Tanzimat'tan Cumhuriyete Türkiye Ansiklopedisi, 1 (İstanbul 1985), ss. 10-26.

Taşdemirci, Ersoy. “Türk Eğitim Tarihinde Azınlık Okulları ve Yabancı Okullar”. Erciyes Üniversitesi Sosyal Bilimler Enstitüsü Dergisi, 10 (2001): 13-30.

Tekin, Mehmet. “Geçmişte ve Günümüzde Hatay'da Eğitim”. Hatay'da Eğitim ve Kültür, Ankara: Milli Eğitim Bakanlığı Yayınları, 1983, 59-86.

Temiz, F. Mine, “XX. Yüzyıl Başlarında Antakya'da Yeni Mimari Oluşumlara İki Örnek: Gündüz Sineması ve Adalı Evi", X. Ortaçăg-Türk Dönemi Kazıları ve Sanat Tarihi Araştırmaları Sempozyumu Bildirileri (Prof. Dr. H. Örcün Barışta 'ya Armă̆an), Ankara: Gazi Üniversitesi Yayınları, 2009, 685699.

Temiz, F. Mine - Kolay, Emre. “Fransız İşgali Altındaki Antakya’nın Değişen Mimari Çehresine Bir Örnek: Saray Caddesi Kuseyri Binası", Hatay (Anavatana Katılışının 80. Yıl Armağanı, (ed. Ahmet Gündüz, Haydar Çoruh, Süleyman Hatipoğlu) İstanbul: Hiper Yayın, 2019, 284-313.

Tuncer, Hüner. "Yirmi Sekiz Çelebi Mehmet Efendi’nin Fransa Sefaretnamesi”. Belleten, LI/199 (1987): 131-151.

Uygun, Selçuk. “Türkiye'de Dünden Bugüne Özel Okullara Bir Bakış (Gelişim ve Etkileri)". Ankara Üniversitesi Ĕ̈itim Bilimleri Fakültesi Dergisi, 36/1-2 (2003): 108-120.

Vahapoğlu, Hidayet. Osmanlıdan Günümüze Azınlık ve Yabancı Okulları, İstanbul: Boğaziçi Yayınları, 1992.

Yorulmaz, Şerife. "Fransız Manda Yönetimi Döneminde İskenderun Sancağı (Hatay)'nın Sosyo-Ekonomik ve Siyasal Durumuna İlişkin Bazı Kayıtlar (1918-1939)". Ankara Üniversitesi Atatürk Yolu Dergisi, 6/22 (1998): 231-259.

Yorulmaz, Şerife. "Osmanl1- Fransız İlişkileri Çerçevesinde Osmanlı Topraklarında Açılan Fransız Kültür Kurumları ve Bunların Meşruiyet Kazanması (19. Yüzyı1-20. Yüzyıl Başları)”, Ankara Üniversitesi Osmanlı Tarihi Araştırma ve Uygulama Merkezi Dergisi, 11 (2000): 697-768. 